IZA DP No. 9830

Child Access Prevention Laws, Youth Gun Carrying, and School Shootings

D. Mark Anderson

Joseph J. Sabia

March 2016 


\title{
Child Access Prevention Laws, Youth Gun Carrying, and School Shootings
}

\author{
D. Mark Anderson \\ Montana State University \\ Joseph J. Sabia \\ University of New Hampshire, San Diego State University \\ and IZA
}
Discussion Paper No. 9830
March 2016

\author{
IZA \\ P.O. Box 7240 \\ 53072 Bonn \\ Germany \\ Phone: +49-228-3894-0 \\ Fax: +49-228-3894-180 \\ E-mail: iza@iza.org
}

\begin{abstract}
Any opinions expressed here are those of the author(s) and not those of IZA. Research published in this series may include views on policy, but the institute itself takes no institutional policy positions. The IZA research network is committed to the IZA Guiding Principles of Research Integrity.

The Institute for the Study of Labor (IZA) in Bonn is a local and virtual international research center and a place of communication between science, politics and business. IZA is an independent nonprofit organization supported by Deutsche Post Foundation. The center is associated with the University of Bonn and offers a stimulating research environment through its international network, workshops and conferences, data service, project support, research visits and doctoral program. IZA engages in (i) original and internationally competitive research in all fields of labor economics, (ii) development of policy concepts, and (iii) dissemination of research results and concepts to the interested public.
\end{abstract}

IZA Discussion Papers often represent preliminary work and are circulated to encourage discussion. Citation of such a paper should account for its provisional character. A revised version may be available directly from the author. 


\title{
ABSTRACT \\ Child Access Prevention Laws, Youth Gun Carrying, and School Shootings*
}

\begin{abstract}
Despite intense public interest in keeping guns out of schools, next to nothing is known about the effects of gun control policies on youth gun carrying or school violence. Using data from the Youth Risk Behavior Surveys (YRBS) for the period 1993-2013, this study is the first to examine the relationship between child access prevention (CAP) gun controls laws and gun carrying among high school students. Our results suggest that CAP laws are associated with a 13 percent decrease in the rate of past month gun carrying and an 18 percent decrease in the rate at which students reported being threatened or injured with a weapon on school property. In addition, we find that CAP laws are associated with a lagged decline in the probability that students miss school due to feeling unsafe. These results are concentrated among minors, for whom CAP laws are most likely to bind. To supplement our YRBS analysis, we collect a novel dataset on school shooting deaths for the period 1991-2013. We find that while CAP laws promote a safer school environment, they have no observable impact on school-associated shooting deaths.
\end{abstract}

JEL Classification: $\quad \mathrm{K} 4, \mathrm{I} 2, \mathrm{H} 7$

Keywords: gun control, youth risky behavior, school violence

Corresponding author:

Joseph J. Sabia

Department of Economics

San Diego State University

5500 Campanile Drive

San Diego, CA 92182-4485

USA

E-mail: jsabia@mail.sdsu.edu

\footnotetext{
* We thank Josh Latshaw, Taylor Mackay, Thanh Tam Nguyen, Usamah Wasif, and John Westall for excellent research assistance. We also thank David Simon, Ulf Zoelitz, and participants at the 2015 Southern Economic Association Annual Meeting, the 2015 Western Economic Association Annual Meeting, the 2015 International Health Economics Association Annual Meeting, the University of South Florida, the United States Military Academy, West Virginia University, and the University of New Hampshire for their comments and suggestions. Partial support for this research came from a Eunice Kennedy Shriver National Institute of Child Health and Human Development research infrastructure grant, R24 HD042828, to the Center for Studies in Demography and Ecology at the University of Washington.
} 


\section{INTRODUCTION}

School shootings, such as the recent high-profile events in Chardon, Ohio; Sparks, Nevada; and Troutdale, Oregon, are usually committed by students of the school who are under the age of 18 (FBI 2002). ${ }^{1}$ In fact, between 2012 and 2015, approximately 70 percent of shootings at K-12 schools were committed by minors (Everytown.org 2015a). More often than not, the shooters obtained their guns from their own home or that of a relative (Violence Policy Center 2001; Wood 2001; Copeland 2014). Based on survey data, roughly one-third of households with children reported that firearms were kept in or around their home (Okoro et al. 2005). Among homes with children and firearms, 43 percent reported having at least one gun in an unlocked place (Schuster et al. 2000). According to the Brady Center (2014), 1.7 million children in the United States live in a home with an unlocked and loaded gun.

Advocates for stricter gun control laws cite the wide availability of firearms to youths as an important risk factor for school violence (Wood 2001; Christakis and Christakis 2012; Vartabedian 2014). In an effort to restrict youth firearm access, a number of states have passed child access prevention (CAP) laws, which impose criminal liability on gun owners who allow children unsupervised access to firearms (Law Center to Prevent Gun Violence 2013). Proponents of CAP laws argue that they not only limit intentional shootings but also accidental ones (Shaffer 1999). On the other hand, opponents of gun control contend that CAP laws impede upon a gun owner's constitutional right to bear arms and defend oneself. In emergency

\footnotetext{
${ }^{1}$ On February 27, 2012, Thomas Lane, a 17 year-old student, brought a .22 caliber handgun he had taken from his grandfather's barn to the Chardon High School cafeteria. He fired 10 rounds, killing three students and injuring two others. (Crimesider staff 2012; Dolak et al. 2012). On October 21, 2013, 12-year-old seventh-grade student Jose Reyes brought a 9-mm semi-automatic handgun from home to the Sparks Middle School playground. He killed one teacher and injured two students before turning the gun on himself. He obtained the weapon from an unlocked case on a shelf above his kitchen refrigerator (Associated Press 2013). On June 10, 2014, 15-year-old freshman Jared Padgett carried an AR-15 assault rifle in a guitar case on the school bus to Reynolds High School. He used it to kill one student and wound a teacher in the boys' locker room before committing suicide (Bernstein 2014). He took the gun from his brother, a member of the U.S. Army Reserve program (Slauson 2014).
} 
situations, they argue that safe storage requirements encumber a potential victim's ability to use a firearm for self-defense (Shaffer 1999; Lott and Whitley 2001).

While a small literature on CAP laws exists (Cummings et al. 1997; Webster and Starnes 2000; Lott and Whitley 2001; Webster et al. 2004; DeSimone et al. 2013), including recent evidence that CAP laws reduce the probability that minors reside in families with unsafely stored weapons (Prickett et al. 2014), no prior studies have estimated the effect of CAP laws on youth gun carrying or gun-related school violence. In fact, we know very little about the effects of gun control policies in general on these outcomes. ${ }^{2}$ Studying the impact of CAP laws is appealing because (1) there is substantial state-level variation in the timing of policy adoption, (2) the laws create predictions as to which age groups should be most affected, and (3) heterogeneity in standards for criminal liability (negligent storage vs. reckless endangerment) generates predictions as to where effects should be most strongly felt.

This study begins by examining the relationship between CAP laws and gun carrying among high school students using data from the Youth Risk Behavior Surveys (YRBS) for the period 1993-2013 when 17 states and the District of Columbia passed CAP laws. ${ }^{3}$ Difference-indifference estimates show that CAP laws are associated with a 13 percent decrease in the rate at which high school students reported carrying a gun in the past month. This result is driven by the students in our sample for whom the laws are more likely to bind, those under the age of 18 . A causal interpretation of this finding is bolstered by the fact that we find no evidence to suggest that CAP laws are associated with gun carrying among high school students 18 years of age and

\footnotetext{
${ }^{2}$ Economists have studied the crime effects of concealed-carry laws (Ludwig 1998), juvenile gun bans (Marvell 2001), right-to-carry laws (Mustard 2001; Aneja et al. 2012), and stand-your-ground laws (McClellan and Tekin 2012; Cheng and Hoekstra 2013), but none have examined the effects of gun control on school violence.

${ }^{3}$ For the YRBS analysis below, data are available for before and after a CAP law went into effect for the District of Columbia and 13 of these 17 states.
} 
older. Importantly, CAP law effects are not isolated to a particular race; such laws appear to deter gun carrying among both white and black students. On the other hand, CAP law effects are isolated among students who are more likely to carry a gun in the first place. From a policy perspective, this result is important because it (i) sheds light on the marginal student affected by CAP laws, and (ii) suggests that we can reject the "selective recruitment" hypothesis.

Turning to outcomes more directly related to a student's own safety, we find that CAP laws are associated with an 18 percent decrease in the rate at which students reported being threatened or injured with a weapon on school property. For students under the age of 18, we also find that CAP laws are associated with large lagged decreases in the rate at which students reported having missed school in the past month due to feeling unsafe.

Finally, we compile the first comprehensive data set of school-associated shooting deaths and examine the relationship between CAP laws and these events. ${ }^{4}$ Our results provide little evidence that CAP laws are associated with school shooting deaths committed by minors. Although imprecise, estimated effects are small and statistically indistinguishable from zero at conventional levels. These results suggest that the benefits of CAP laws may not extend to deterring these rare, but tragic events.

\subsection{Youth Gun Violence}

\section{BACKGROUND}

Highly publicized school shootings have increased awareness on youth firearm access and use. A large literature exists on the individual-level correlates of youth gun carrying. Researchers have found that mental health (Saukkonen et al. 2015), victimization (Ruggles and

\footnotetext{
${ }^{4}$ Using a sample of Chicago high school students, Chandler et al. (2011) studied the individual-level determinants of getting shot.
} 
Rajan 2014; Saukkonen et al. 2015), parental involvement (Vaughn et al. 2012), substance use (Hemenway 1996; Ruggles and Rajan 2014), academic performance (Hemenway et al. 1996), and drug dealing (Vaughn et al. 2012), are all strong predictors of youth gun carrying. ${ }^{5}$

Teens who own guns for sport typically have parents who socialize them into gun use and are unlikely to be involved in criminal activity. On the other hand, teens who obtain guns illegally are generally socialized into gun use by their peers, more likely to be criminally active, and more likely to bring guns to school (Lizotte et al. 1994; Lizotte et al. 1997). These teens may impose substantial costs on others. For example, beyond the direct costs borne by victims and their families, gun-related school violence may have far-reaching consequences for educational attainment. Grogger (1997) found that increased levels of violence in and around schools led to lower graduation rates in the United States. Beland and Kim (forthcoming) found that fatal shootings in U.S. high schools were associated with increased dropout rates and reduced test scores for those students who remained enrolled, while Abouk and Adams (2013) found evidence to suggest that school shootings induced private school enrollment. Poutvaara and Ropponen (2010) concluded that a highly publicized school shooting in Finland even decreased the academic performance of students in other schools. ${ }^{6}$

In the absence of shootings, student gun carrying alone may create a school environment that hinders academic performance. Researchers have established that school safety is correlated with test scores (Arum 2003; Lacoe 2013), classroom engagement (Ripski and Gregory 2009), absenteeism (Bryk and Thum 1989), and dropout rates (Rumberger 1995). Studies have also

\footnotetext{
${ }^{5}$ See Emmert and Lizotte (2015) for a thorough discussion of the research on the demographics of youth weapon carriers and the individual-level risk factors for juvenile weapon carrying.

${ }^{6}$ Relatedly, Gershenson and Tekin (2015) found that the 2002 "Beltway Sniper” attacks in Washington, D.C. reduced school-level proficiency rates in schools within five miles of an attack. They concluded that traumatic community events such as mass shootings have the potential to disrupt student learning.
} 
found that students who fear that their classmates may be carrying guns are more likely to carry themselves (Bergstein et al. 1996; Hemenway et al. 1996; Hemenway et al. 2011).

\subsection{CAP Laws}

While there are no CAP laws at the federal level, state CAP laws have been around for over 30 years. In 1981, Missouri passed the first law aimed at punishing adults who give children unsupervised access to firearms. Since 1981, 26 states and the District of Columbia have passed a CAP law. As of 2014, 13 states were considering some form of CAP legislation (Patel 2014).

The strongest CAP laws impose criminal liability when a minor gains access to a firearm that has been stored negligently. If a child uses a firearm that was not properly locked up or stored to injure or kill a person, CAP laws penalize the gun owner with fines, imprisonment, or a combination of both. For example, based on California's recently signed Firearm Safe and Responsible Access Act, violators risk a potential \$1,000 fine and/or six months in jail (Peters 2013a). To take another example, Massachusetts imposes a minimum \$5,000 fine and/or 2.5 years in jail for those who allow children unsupervised access to handguns. ${ }^{7}$ Within the law, owners are not required to use particular locks or methods of storage and may choose from a variety of options, so long as their guns are inaccessible to children (Shaffer 1999). On the other hand, some states impose a weaker standard for criminal liability and forbid persons from “intentionally, knowingly, and/or recklessly providing some or all firearms to children” (Law Center to Prevent Gun Violence 2013). CAP laws have also been used to penalize

\footnotetext{
${ }^{7}$ See Young (2012) and Harmacinski (2013) and for stories on individuals charged with violating their state’s safe storage law.
} 
manufacturers, dealers, and importers who fail to include safety devises with the sale of their firearms (Shaffer 1999). ${ }^{8}$

CAP law prosecutions are most common when police are investigating other crimes, including gun violations (i.e., "stacking” of criminal charges), but also occur when police are given tips on unsafely stored firearms. Perhaps understandably, there is some reticence on the part of prosecutors to charge parents with violations of CAP laws if their child completed suicide or an accidental death occurred (Peters 2013b; Lithwick 2015).

Recent evidence suggests that CAP laws reduce the ease with which minors can access firearms. Using data from the Early Childhood Longitudinal Study, Prickett et al. (2014) found that CAP laws, particularly in states with stronger gun control policies, are associated with a diminished likelihood that a child lives in a household with an unsafely stored firearm. ${ }^{9}$ While no previous studies have focused on school-related outcomes, several have used state-level data to examine the relationship between CAP laws and gun-related deaths. Using data for the period 1979-1994, Cummings et al. (1997) found that CAP laws were associated with a decrease in accidental shooting deaths by roughly 23 percent among children 14 years of age and younger. Using data for the period 1979-1997, Webster and Starnes (2000) also examined the relationship between CAP laws and accidental shooting deaths among children 14

\footnotetext{
${ }^{8}$ It should also be noted that CAP laws vary along other margins. For instance, some states impose criminal liability only if the child actually uses or carries the firearm. CAP laws may apply to all firearms, loaded firearms, or handguns only. Some states require that firearms not only be stored, but must be done so with a locking device in place. The age at which a state defines a "minor" also varies. While the majority of states define a minor as anyone under the age of 18, some states operate under a lower age threshold (Law Center to Prevent Gun Violence 2013). In our YRBS sample, three states that changed their CAP laws defined a "minor" more narrowly than individuals under the age of 18. Illinois, New Hampshire, and Texas classified minors at ages 13 and younger, 15 and younger, and 16 and younger, respectively. Given this information and the fact that our approach defines the treated group as students in CAP law states who are under the age of 18, we potentially capture a lower bound policy effect. However, (i) dropping these states from our estimation sample, or (ii) restricting each state's sample of students based on their own definition of a "minor", yields a similar pattern of results.

${ }^{9}$ On a related note, Cook and Ludwig (2004) found that the prevalence of gun ownership in a community predicted gun carrying among adolescent males.
} 
years of age and younger. They found a negative association between CAP laws and accidental firearm deaths, but this association was entirely driven by one state (Florida). Webster et al. (2004) found that CAP laws were associated with an 11 percent decrease in the gun-related suicide rate among 14- to 17-year-olds for the period 1976-2001. These authors also found that CAP laws were associated with a similar decrease in the gun-related suicide rate among 18- to 20-year-olds, raising the possibility that their findings for the younger age group were spurious. Using data for the period 1979-1996, Lott and Whitley (2001) found little evidence to suggest that CAP laws were associated with accidental gun deaths or suicides among teens.

Most recently, DeSimone et al. (2013) used annual hospital discharge data for the period 1988-2003 to estimate the relationship between CAP laws and nonfatal gun injuries. They found that CAP laws were associated with 26 and 5 percent decreases in self-inflicted and non-selfinflicted gun injuries, respectively, among individuals under the age of 18. Supporting a causal interpretation, they found no effects on self-inflicted gun injuries among adults or on selfinflicted injuries without a gun.

Our study contributes to the above literature by being the first to examine the effect of CAP laws on youth gun carrying and school violence. We also compile the first census of school-associated shooting deaths in the United States over the last two decades and explore the relationship between CAP laws and these events.

\section{YRBS ANALYSIS}

\subsection{YRBS Data}

The data for our primary analysis come from the national and state YRBS and cover the period 1993-2013. Government agencies rely on these data to track trends in teen behaviors 
including physical activity, unhealthy eating, tobacco use, alcohol and other drug use, sexual activity, and violence. Previous studies such as Simon et al. (1999), Dinkes et al. (2009), and Sabia and Bass (2015) have used these data to examine determinants of weapon carrying and student victimization on school grounds. ${ }^{10}$

The national YRBS is carried out biennially by the Centers for Disease Control and Prevention (CDC) and is representative of the population of high school students in the United States. ${ }^{11}$ We obtained the restricted-use versions of the national YRBS so respondents could be linked to their state of residence. The state surveys, which are also biennial and school-based, are coordinated by the CDC, administered by state education and health agencies, and mirror the national surveys in terms of content. ${ }^{12}$ Roughly half of the states have granted the CDC permission to release their data, while the remaining states require direct data requests.

Following previous studies, we combine the national and state YRBS data so that identification comes from as many law changes as possible (Sabia et al. 2014; Hansen et al. 2015; Anderson and Elsea 2015, Anderson et al. 2015). Between 1993 and 2013, 13 states and the District of Columbia contributed data to the national or state YRBS before and after the adoption of a CAP law (see Table 1). Six of these states and the District of Columbia impose criminal liability for negligent storage, while seven states impose criminal liability for reckless endangerment. In combination, the YRBS data cover all 50 states and the District of Columbia.

First, we measure youth gun carrying (Carry Gun) using responses to the following YRBS questionnaire item:

\footnotetext{
${ }^{10}$ Researchers have used these data to study a wide of a range of state policies. For examples, see Cawley et al. (2007), Carpenter and Stehr (2008), Anderson (2010), Hansen et al. (2013), and Anderson et al. (2015).

${ }^{11}$ Although designed to be nationally representative, not all 50 states contributed data to the national YRBS in any given survey wave.

${ }^{12}$ With a few exceptions, most states conducted their own YRBS at some point between 1993 and 2013.
} 
"During the past 30 days, on how many days did you carry a gun?"

Carry Gun is equal to 1 if the respondent reported carrying a gun at least once in the past 30 days, and equal to 0 otherwise. ${ }^{13}$

Respondents are then asked about weapons carrying, both overall and on school property, which we use to generate two separate indicators:

"During the past 30 days, on how many days did you carry a weapon such as a gun, knife, or club?"

"During the past 30 days, on how many days did you carry a weapon such as a gun, knife, or club on school property?"

Carry Any Weapon (at School) is equal to 1 if the respondent reported carrying a weapon (on school property) at least once in the past 30 days, and equal to 0 otherwise. The obvious disadvantage of these two measures is that we cannot separate out gun carrying effects of CAP laws from knife or club carrying effects. Thus, we can only observe the total effect of CAP laws on weapon carrying and are unable to examine whether knives or other weapons are complements to or substitutes for guns. However, a comparison of the estimated effect of CAP laws on Carry Gun and Carry Any Weapon will provide at least some evidence as to whether substitution across weapons exists.

Respondents are also asked whether they faced a weapons-related threat or injury on school property:

\footnotetext{
${ }^{13}$ We also examined the intensive margin of gun carrying, as well as the intensive margin for outcomes for which we have measures of frequency. These results, which are available upon request, suggest that CAP law effects tend to be largest on the extensive margin.
} 
"During the past 12 months, how many times has someone threatened or injured you with a weapon such as a gun, knife, or club on school property?"

Weapon Threat at School is equal to 1 if the respondent reported being threatened or injured at least once in the past 12 months, and equal to 0 otherwise. Finally, respondents are asked:

"During the past 30 days, on how many days did you not go to school because you felt you would be unsafe at school or on your way to or from school?"

Missed School Due to Safety is equal to 1 if respondents reported missing school at least once in the last 30 days, and equal to 0 otherwise.

Table 2 provides descriptive statistics and definitions for the YRBS data. Means are reported by whether a CAP law was in place during the year of the survey. According to the YRBS data, 5.5 percent of high school students carried a gun at least once in the past 30 days, 17.6 percent carried a weapon (i.e., a gun, knife, or club) in the past 30 days, 6.0 percent carried a weapon on school property in the past 30 days, 7.1 percent were threatened or injured with a weapon on school property at least once in the past year, and 5.3 percent missed school due to feeling unsafe in the past 30 days. ${ }^{14}$ An advantage of the first three outcomes (Carry Gun, Carry Any Weapon, and Carry Any Weapon at School) is that there are clear predictions as to which age groups should be most influenced by CAP laws. The laws are less binding for students 18 years of age and older than for students under the age of 18. However, because some of these older students live with younger individuals, there may be spillover effects. It is less clear that

\footnotetext{
${ }^{14}$ An advantage of considering the weapons threat and school absence outcomes is that they are less likely to suffer from underreporting than the responses related to the carrying of guns and weapons.
} 
CAP laws should impact the latter two outcomes (Weapon Threat at School and Missed School Due to Safety) differently across the two age groups.

Figures 1 and 2 show trends in our dependent variables for the national and state YRBS, respectively. These figures illustrate that the national and state YRBS are each capturing the same broad changes in our outcomes over time. During the 1990s, rates of weapon carrying declined substantially; at the same time, rates of safety-related absences and weapons-related threats at school rose. After 2001, the rates for all of our outcomes of interest remained steady.

\subsection{YRBS Empirical Strategy}

Our empirical analysis is reduced-form, based on the approach taken by previous researchers interested in the effects of gun laws. ${ }^{15}$ Specifically, to estimate the relationship between CAP laws and high school student outcomes, we exploit the spatial and temporal variation of these laws in a standard differences-in-differences framework. Our estimating equation is:

$$
Y_{i s t}=\beta_{0}+\beta_{1} C A P L a w_{s t}+\boldsymbol{X} \mathbf{1}_{i s t} \boldsymbol{\beta}_{2}+\boldsymbol{X} \boldsymbol{2}_{s t} \boldsymbol{\beta}_{3}+v_{s}+w_{t}+v_{s} \cdot t+\varepsilon i s t,
$$

where $i$ indexes individuals, $s$ indexes states, and $t$ indexes years. The dependent variable, $Y_{i s t}$, represents one of the five possible outcomes listed in Table 2 (Carry Gun, Carry Any Weapon, Carry Any Weapon at School, Weapon Threat at School, Missed School Due to Safety). ${ }^{16}$ The

\footnotetext{
${ }^{15}$ For examples, see Ludwig (1998), Marvell (2001), Mustard (2001), McClellan and Tekin (2012), Cheng and Hoekstra (2013), and DeSimone et al. (2013).

${ }^{16}$ The YRBS defines a weapon as an object such as a "gun, knife, or club." Ideally, we would like to only observe gun carrying or gun threats on school property. However, if CAP laws restrict gun access among teens and other weapons such as knives or clubs serve as substitutes for firearms, then our estimates based on the outcomes Carry Any Weapon, Carry Any Weapon at School, and Weapon Threat at School will be conservative.
} 
variable of interest, CAP Lawst, is an indicator for whether state $s$ was enforcing a CAP law in year $t .^{17}$ In alternate specifications, we allow the type of CAP law to vary by whether the state enforces a negligent storage or reckless endangerment criminal liability standard. The vectors $v_{s}$ and $w_{t}$ represent state fixed effects and year fixed effects, respectively, and state-specific linear time trends are denoted by $v_{s} \cdot t$. The state-specific linear time trends are included to control for state-level factors that evolve smoothly over time, such as sentiment towards gun control.

The vector $\boldsymbol{X} \boldsymbol{1}_{\text {ist }}$ includes individual-level controls for race, age, grade, and gender, while the vector $\boldsymbol{X} \boldsymbol{2}_{\text {st }}$ includes state-level controls for demographics (\% Black, Mean Age, \% Male), economic conditions (Unemployment, Per Capita Income), education levels and the schooling environment (\% Bachelor's Degree, Student-Teacher Ratio, School Lunch Program, Teacher Salary, Zero Tolerance Law, Anti-Bullying Law), policing resources (Police Expenditures, Police Employment), the crime rate (Property Crime, Violent Crime), political preferences (Democrat), other gun laws (Shall Issue Law, Stand Your Ground Law), whether the state mandates insurance coverage to include mental health benefits at parity with physical health benefits (Mental Health Parity Law), and beer taxes (Beer Tax). ${ }^{18}$

\footnotetext{
${ }^{17}$ This variable takes on fractional values during the year in which a CAP law took effect.

${ }^{18}$ The state-level demographics were calculated using population data from the National Cancer Institute's Surveillance Epidemiology and End Results Program. The unemployment and income data are from the Bureau of Labor Statistics and the Bureau of Economic Analysis, respectively. The data on the state population share with a bachelor's degree are from the U.S. Department of Education, while the data on student-teacher ratios and teacher salaries come from annual issues of the Digest of Education Statistics published by the National Center for Education Statistics. Information on school lunch participation rates comes from the U.S. Department of Agriculture. Information on zero tolerance school violence laws comes from the Law Center to Prevent Gun Violence and the Education Commission of the States. The effective dates for the anti-bullying laws are from Sabia and Bass (2015). Police expenditure and employment statistics are from the Bureau of Justice Statistics and crime rates were calculated based on the FBI's Uniform Crime Reports. Information on whether a state had a Democratic governor in office was gathered through our own internet searches. For the period 1993 through 2011, information on shall issue gun laws comes from Grossman and Lee (2008), Donohue and Ayres (2009), and Aneja et al. (2012). For 2012 and 2013, information on shall issue gun laws comes from Hinkston (2012), the United States Government Accountability Office (2012), Arnold (2015), and USA Carry (2015). The effective dates for the mental health parity laws are from Lang (2013). Updates to the laws in Lang (2013) were provided via personal correspondence with the author. The data on beer taxes come from the Beer Institute's Brewers Almanac. Researchers have relied on beer taxes to proxy variations in the price of alcohol (Ruhm 1996; Markowitz et al. 2005).
} 
All regressions are estimated as probit models and standard errors are corrected for clustering at the state level (Bertrand et al. 2004). To ensure the combined YRBS data are nationally representative, we used population data from the National Cancer Institute's Surveillance Epidemiology and End Results Program (http://seer.cancer.gov/popdata/) and assigned population weights to each respondent based on state of residence, age, gender, and race (Hansen et al. 2015; Anderson and Elsea 2015, Anderson et al. 2015).

In order for equation (1) to generate unbiased estimates of the effect of CAP laws on gun carrying and school violence, the parallel trends assumption must be satisfied. We take three approaches to test this assumption: (1) examine whether effects are stronger for minor as compared to non-minor high school students, for whom CAP laws are more binding, (2) conduct placebo tests on policy leads, and (3) provide falsification tests on behaviors that should be unaffected by CAP laws, such as exercise, diet, and substance use.

\subsection{YRBS Results}

Table 3 presents the main results from the YRBS analysis. Panel I illustrates results for the full sample of high school students, while panels II and III split the sample by age. Because CAP laws specifically target households with minor children, we present results based on an age 18 cutoff. While the results in panel III do not represent a perfect falsification test (because high school students 18 years of age and older may live in households with younger individuals), we expect CAP laws to be much less binding for this age group. ${ }^{19}$

For the full sample (Panel I), CAP laws are associated with a .007 decrease in the probability a high school student carried a gun within the past 30 days and a .016 decrease in the

\footnotetext{
${ }^{19}$ For example, according to wave 1 of the National Longitudinal Study of Adolescent Health, 50.4 percent of 18 year-olds surveyed reported having a younger sibling.
} 
probability a high school student carried any weapon (i.e., a gun, knife, or a club) within the past 30 days. Both of these estimates are statistically significant at the 10 percent level and reflect roughly 13 and 9.5 percent decreases relative to the mean rates of gun carrying and weapon carrying, respectively, in states without a CAP law. While tests of differences in these coefficients cannot rule out substitution across types of weapons, the results suggest that CAP laws are effective at reducing net weapons carrying, at least across the range of weapons examined in the YRBS. CAP laws are also negatively associated with high school students having reported carrying a weapon specifically on school property, but this estimate is not statistically distinguishable from zero at conventional levels.

With regard to a student's own safety, we find that CAP laws are associated with a .013 decrease in the probability a student was threatened or injured with a weapon on school property within the past year. This represents roughly an 18 percent decrease relative to the mean. We also find that CAP laws are associated with a (statistically insignificant) .006 decrease in the probability a student missed school within the past 30 days because he/she felt unsafe.

Panels II and III in Table 3 illustrate that the statistically significant estimates for the full sample are driven by the age group for which the laws bind (i.e., students under 18 years of age). Specifically, for the outcomes Carry Gun, Carry Any Weapon, and Weapon Threat at School, CAP laws are associated with an approximate 18, 11, and 22 percent decrease in the probability of each, respectively. ${ }^{20}$ The across-the-board null findings shown in Panel III provide confidence that our estimates in Panel II are not spurious and potentially reflect a causal relationship between CAP laws and gun-related outcomes among high school students.

\footnotetext{
${ }^{20}$ Appendix Table 1 presents means for the outcomes by age.
} 
Next, we interact CAP Law with Shall Issue to test whether CAP laws are more effective in stricter gun control environments (Prickett et al. 2014). Our findings in Table 4 are generally consistent with this hypothesis. For students under the age of 18, when shall issue laws are not being enforced (i.e., tougher gun control), the effect of CAP laws on Carry Gun is 0.8 percentage-points larger (in absolute magnitude). For the remaining results in Panel II of Table 4, the interactive effect of Shall Issue and CAP Law is positive in sign for three of the four cases, but is never statistically significant. ${ }^{21}$

In Table 5, we replace CAP Law with two mutually exclusive indicators, Negligent Storage and Reckless Endangerment, to examine whether heterogeneous effects exist by the type of CAP law in place. As discussed above, negligent storage laws are the strongest form of CAP laws and impose criminal liability when a minor gains access to a negligently stored firearm. On the other hand, some states impose a weaker standard for criminal liability and prohibit persons from "intentionally, knowingly, and/or recklessly providing some or all firearms to children" (Law Center to Prevent Gun Violence 2013).

The results in Table 5 are consistent with the notion that negligent storage laws are more effective than reckless endangerment laws when it comes to reducing gun carrying among high school students and providing a generally safer school environment. ${ }^{22}$ Again, we see that the results are strongest for respondents under the age of 18 as compared to non-minors (Panel I versus Panel II).

\footnotetext{
${ }^{21}$ When we examine the effect of other gun control laws (Shall Issue and Stand Your Ground) or mental health parity laws (Mental Health Parity), we find no evidence of a relationship between these policies and our outcomes of interest.

${ }^{22}$ We do find some statistically significant evidence that reckless endangerment CAP laws reduce the likelihood a student reports being threatened or injured with a weapon on school property. However, we fail to reject the hypothesis that reckless endangerment laws are more effective than negligent storage laws for this particular outcome.
} 
Next, we explore whether the relationship between CAP laws and our outcomes of interest depends on race. In Table 6, we present results separately for white (Panel I) and black (Panel II) students. This is an important margin to consider because school- and communitylevel correlates with race, such as socioeconomic status, gang presence, and urbanicity, have been shown to be strong predictors of school violence and victimization (Laub and Lauritsen 1998; Mayer and Leone 1999; Warner et al. 1999).

We find that CAP laws appear effective at reducing gun carrying among both white and black high school students. Specifically, CAP laws are associated with a .010 decrease in the probability of gun carrying within the past 30 days for white students and a .012 decrease in the probability of gun carrying for black students. ${ }^{23}$ For white students, CAP laws are also associated with statistically significant decreases in weapon carrying and weapon threats received at school. The relationship between CAP laws and school absences for fear of safety, while negative, is statistically insignificant. For black students, CAP laws are also associated with statistically significant decreases in weapon carrying and weapon carrying at school. The relationship between CAP laws and weapon threats received at school, while negative, is statistically insignificant. $^{24}$

In Tables 7A, 7B, and 8, we conduct a series of falsification tests to examine whether our difference-in-difference estimates are contaminated by differential unmeasured state-specific time trends. Table 7A presents results based on regressions where we replace CAP Law with an indicator Year of Law Change, 2 leads of this indicator, and 2 lags. Year of Law Change is equal

\footnotetext{
${ }^{23}$ These estimates represent 19.6 and 20.3 percent decreases relative to the mean rates of gun carrying among white and black students, respectively, in states without a CAP law. Appendix Table 2 presents means for the outcomes by race.

${ }^{24}$ We also explored whether the relationship between CAP laws and our outcomes of interest depends on gender. Across all outcomes, we failed to reject the hypothesis that CAP laws were more effective for males as compared to females.
} 
to one the year in which a CAP law went into effect and is equal to zero otherwise. ${ }^{25}$ The primary purpose of this exercise is to test whether any of the outcomes were trending in the years prior to the law change. Consistent with the parallel trends assumption, there is little evidence to suggest that our outcomes of interest were trending in a systematic fashion leading up to the passage of CAP laws. From this exercise, we also see that there is a lagged CAP law effect, suggesting their impact is felt in the years after the law is implemented rather than immediately. This appears to especially be the case for outcomes related to a student's own safety. Our findings are consistent with evidence that policies often take time to change behavior due to, for example, information acquisition and costs of adjustment (Kuo 2012; Taylor and Li 2015).

Table 7B repeats this exercise but with a focus on negligent storage laws, the type of CAP laws that appear to be driving our results. Again, the evidence suggests the parallel trends assumption holds and there is a lagged CAP law effect. Consistent with the results from Table 4, negligent storage laws have the strongest effects on gun carrying and school safety.

In Table 8, we conduct falsification tests on behaviors for which we would expect no causal effect of CAP laws. Specifically, we consider binary outcomes for cigarette use, marijuana use, cocaine use, binge drinking, drunk driving, seatbelt use, helmet use, having had multiple sex partners, exercise, diet pill use, and fruit consumption. ${ }^{26}$ If CAP laws were found to be negatively associated with these outcomes for students under the age of 18 , it could suggest that difference-in-difference estimates produced by equation (1) are spurious in nature. However, the findings in Table 8 suggest no evidence of a statistically significant association

\footnotetext{
${ }^{25}$ This variable takes on fractional values during the year in which a CAP law took effect.

${ }^{26}$ Appendix Table 3 provides descriptive statistics for the outcomes used as falsification tests.
} 
between any of these behaviors and CAP laws. These results provide further support for the hypothesis that the parallel trends assumption is satisfied.

Lastly, we split the sample along several risky behaviors and explore the "selective recruitment" hypothesis; that is, that students who are most likely to carry guns are those least likely to be influenced to the law. ${ }^{27}$ In Table 9, we consider our three weapon-carrying outcomes and split the sample by reports of past month marijuana use, binge drinking, and drunk driving. While we recognize that these behaviors are potentially endogenous, we note that gun and weapons carrying are positively correlated with each. ${ }^{28}$ Across all three types of risky behaviors, we can reject the selective recruitment hypothesis. CAP law effects are isolated among those students who reported past month substance use and drinking and driving. ${ }^{29}$ One explanation for these results may be that CAP laws particularly affect the behavior of parents who believe their children have a propensity for seeking access to firearms.

\section{SCHOOL SHOOTING ANALYSIS}

The estimates above suggest that CAP laws play an important role in decreasing the likelihood that high school students report carrying a gun in the past month or a weapon on school property in the past month. Our results also suggest that students are less likely to be threatened or injured with a weapon on school property or miss school for fear of their safety

\footnotetext{
27 The selective recruitment hypothesis has also been studied within the context of seat belt laws and anti-drug campaigns (Dee 1998; Carpenter and Stehr 2008; Anderson 2010).

${ }^{28}$ Appendix Table 4 provides descriptive statistics by reports of past month marijuana use, binge drinking, and drunk driving for the three weapon-carrying outcomes. Not surprisingly, students who are more likely to use substances and drive drunk are also more likely to carry guns.

${ }^{29}$ Given interest on the link between mental health and gun violence, we also split our sample based on recent suicide ideation (Konnikova 2014; Said 2015). For our three measures of weapon carrying, we failed to reject the hypothesis of equal CAP law effects across the two samples.
} 
when a CAP law is in place. In this section, we test whether the impact of CAP laws extends to school shootings.

\subsection{School Shooting Data}

To our knowledge, this study is the first to compile a comprehensive account of school shootings in the United States during the period under study. Our primary source for data on school shootings comes from the National School Safety Center's (NSSC) report on School Associated Violent Deaths and covers the period 1992 through 2010. ${ }^{30}$ To supplement the NSSC's report and ensure a comprehensive coverage of school shootings, we also used the following data sources: Lieberman (2008), Fleet and Fleet (2010), National School Safety and Security Services (2010), Klein (2012), Stoptheshootings.org (2013), Columbine-angels.com (2015), Doll (in press), and Everytown.org (2015b). These sources, in addition to our own searches of newspaper archives, allowed us to extend our coverage from 1991 to $2013 .^{31}$

For the analysis below, we restrict our focus to school shootings where a death occurred (homicide, suicide, or accidental). By making this restriction, we are confident that our data set represents the first census of school-associated shooting deaths in the United States in existence. Our final data set includes information on when and where the shooting took place, the age of the shooter, and (when available) whether the shooting was reported as gang-related. We define a school shooting as an event that takes place on school property. This includes shootings on school buses and in areas outside of the main building, such as school parking lots and athletic fields. Appendix Table 5 presents descriptive statistics and definitions for our outcome

\footnotetext{
${ }^{30}$ The NSSC report can be found at: http://www.schoolsafety.us/media-resources/school-associated-violent-deaths.

${ }^{31}$ In order to capture additional policy variation, we collected data on school shootings for a longer period than YRBS data were available. However, to match the time span covered by the YRBS data, we also ran our school shooting analysis for the period 1993-2011. These results were similar to those reported below.
} 
measures. For our sample, we identify a total of 402 school shootings involving a death on school property. Of these shootings, we were able to confirm that 164 were committed by individuals under the age of 18.

\subsection{School Shooting Empirical Strategy}

To explore the relationship between CAP laws and school-associated shooting deaths, we generate a state-by-year panel from our individual school shooting data and estimate the following difference-in-difference model:

$$
Y_{s t}=\beta_{0}+\beta_{1} C A P L a w_{s t}+\boldsymbol{X}_{s t} \boldsymbol{\beta}_{2}+v_{s}+w_{t}+v_{s} \cdot t+\varepsilon s t,
$$

where $s$ indexes states and $t$ indexes years. The binary dependent variable, $Y_{s t}$, indicates whether there was a school shooting in state $s$ during year $t$, defined as one of the nine possible school shooting outcomes listed in Appendix Table 5. The variable of interest, CAP Lawst, is defined as above and $v_{s}, w_{t}$, and $v_{s} \cdot t$ represent state fixed, year fixed effects, and state-specific linear time trends, respectively. The vector $\boldsymbol{X}_{\boldsymbol{s}}$ includes the same state-level controls used in equation (1). All regressions are estimated as OLS models and are weighted by the population of state $s$ in year $t .^{32}$ Standard errors are corrected for clustering at the state level (Bertrand et al. 2004). We also experimented with using counts of school shooting deaths by state and year. ${ }^{33}$ Poisson models produced results that were qualitatively similar to those reported below.

\footnotetext{
${ }^{32}$ To retain sample size, we opted to use a linear probability model because the state fixed effects perfectly predicted the outcome for states with no school-associated shooting deaths. Probit models did, however, yield similar results.

${ }^{33}$ For our sample, 74 shootings resulted in two or more persons killed and 30 resulted in three or more persons killed.
} 


\subsection{School Shooting Results}

Table 10 presents estimates of $\beta_{1}$ from equation (2). Panel I shows results for all school shootings, whereas Panels II and III illustrate results separately by the age of the shooter. We disaggregate all death-related school shooting events (column 1) into those involving a suicide (column 2) and a homicide (column 3). In general, we find no statistically significant evidence to suggest that CAP laws are associated with fewer school-associated shooting deaths. For all three panels, estimates in the first two columns are positive, while the estimates for shootings involving a homicide are negative. However, we note that these estimates are sufficiently imprecise to conclusively rule out non-trivial effects of CAP laws. The 95 percent confidence interval associated with the relationship between CAP laws and homicides committed by shooters under the age of 18 is [-.231, .194]. ${ }^{34}$

We next subjected the null findings to a number of sensitivity checks. First, because our school shooting data set includes some gang-related events, we focused on shootings where there was no mention of gang involvement. ${ }^{35}$ These types of shootings are more often considered “random acts of violence” and are less likely to be related to the community’s underlying trend of violent crime (Midlarsky and Klain 2005). We found no evidence to suggest that CAP laws are effective at reducing the likelihood of these events. Second, we replaced CAP Law with an indicator for the year of the law change and a series of leads and lags. Unlike the YBRS results in Tables 7A and 7B, we found no evidence of a lagged CAP law effect. ${ }^{36}$ Third, we examined

\footnotetext{
${ }^{34}$ For the variables Shall Issue Law and Stand Your Ground Law, it is worth noting that we found evidence of a negative relationship between these measures of gun control and our three outcomes for shooters under the age of 18. However, none of these estimates were statistically significant at conventional levels.

${ }^{35}$ We were able to link 45 of the events in our sample to gang involvement.

${ }^{36}$ These results are reported in Appendix Table 6. It is important to note that this table provides little evidence that school shootings were trending upward prior to the enactment of CAP laws. This, to an extent, alleviates the concern that CAP laws are enacted in response to gun-related violence. We also experimented with regressing our
} 
whether there were heterogeneous effects by the type of law in place. We found no systematic evidence of a differential impact of CAP laws by whether a state enforces a negligent storage or reckless endangerment law. Finally, we examined interactive effects of shall issue laws with CAP laws, but found no consistent evidence that CAP laws are associated with reduced school shootings in states that are or are not enforcing shall issue laws. ${ }^{37}$

In sum, while CAP laws appear to decrease gun carrying among high school students and generally promote a safer school environment, they do not have an observable impact on schoolassociated shooting deaths.

\section{CONCLUSION}

The National Poll on Children’s Health, an annual survey conducted by the C.S. Mott Children's Hospital at the University of Michigan, recently indicated that adults ranked school violence and gun-related injuries as two of their top 10 concerns for the health of children in the United States. ${ }^{38}$ These concerns are perhaps driven by the fact that school shootings have been reported at nearly a weekly rate since 2012 (Everytown.org 2015b). While there is a wealth of research on the individual-level correlates of youth gun carrying (Emmert and Lizotte 2015), we know very little about whether specific policies may be leveraged to curb this behavior.

measure of violent crime on leads and lags of CAP laws. We found no evidence that violent crime rates were trending prior to the enactment of CAP laws.

${ }^{37}$ For the sake of brevity, we have omitted the results focusing on non-gang related shootings, negligent storage versus reckless endangerment laws, and the interaction between CAP and shall issue laws. Because some states define a minor based on an age threshold lower than 18, we also experimented with (i) dropping these states from our estimation sample, and (ii) restricting each state's sample of shootings based on their own definition of a "minor." Under both scenarios, we found no evidence that CAP laws are associated with fewer school-associated shooting deaths. All of these results are available from the authors upon request.

${ }^{38}$ School violence ranked $5^{\text {th }}$ and gun-related injuries ranked $9^{\text {th }}$. Results from the poll are available at http://mottnpch.org/blog/2014-08-29/top-10-us-childrens-health-concerns-2014. 
This paper draws on data from two sources to examine the effects of child access prevention laws. Using data from the Youth Risk Behavior Surveys for the period 1993-2013, we find that CAP laws are associated with substantial declines in rates of gun carrying among high school students. These results are driven by students of an age for whom the laws bind and are stronger in states with stricter forms of enforcement. We also find that CAP laws are associated with fewer reports of being threatened or injured with a weapon on school property and decreased rates of school absences due to feeling unsafe. Importantly, CAP laws appear to provide a safer school environment for both white and black students. From an education perspective, these results are vital as school climate is a well-known predictor of academic success. Lastly, we find no evidence to support the "selective recruitment" hypothesis.

Finally, to supplement our YRBS analysis, we explore the relationship between CAP laws and school-associated shooting deaths. Using a novel data set that covers the period 19912013, we find no statistically significant evidence that CAP laws reduce school-associated shooting deaths. However, because these estimates are quite imprecise, we cannot rule out beneficial (or adverse) effects of CAP laws on school shooting deaths. Future research examining the effectiveness of other gun and anti-school violence policies will be critical to curbing these rare, but tragic and costly, events. 


\section{REFERENCES}

Abouk, Rahi and Scott Adams. 2013. "School Shootings and Private School Enrollment.” Economics Letters, Vol. 118, No. 2, pp. 297-299.

Anderson, D. Mark. 2010. "Does Information Matter? The Effect of the Meth Project on Meth Use among Youths." Journal of Health Economics, Vol. 29, No. 5, pp. 732-742.

Anderson, D. Mark and David Elsea. 2015. "The Meth Project and Teen Meth Use: New Estimates from the National and State Youth Risk Behavior Surveys." Health Economics, Vol. 24, No. 12, pp. 1644-1650.

Anderson, D. Mark, Benjamin Hansen, and Daniel I. Rees. 2015. "Medical Marijuana Laws and Teen Marijuana Use." American Law and Economics Review, Vol. 17, No. 2, pp. 495528.

Aneja, Abhay, John Donohue, and Alexandria Zhang. 2012. "The Impact of Right to Carry Laws and the NRC Report: The Latest Lessons for the Empirical Evaluation of Law and Policy." NBER Working Paper 18294.

Arnold, Larry. 2015. "The History of Concealed Carry, 1976-2011." Available at: http://www.txchia.org/history.htm.

Arum, Richard. 2003. Judging School Discipline: The Crises of Moral Authority. Cambridge, Massachusetts: Harvard University Press.

Associated Press. 2013. "Gun Used in Nevada Teacher Killing Wasn't Locked Away: Shooter's Parents." NY Daily News, November 7. Available at: http://www.nydailynews.com/news/national/gun-nevada-teacher-shooting-wasn-lockedarticle-1.1509274.

Beland, Louis-Philippe and Dongwoo Kim. "The Effect of High School Shootings on Schools and Student Performance.” Forthcoming at Educational Evaluation and Policy Analysis.

Bergstein, Jack, David Hemenway, Bruce Kennedy, Sher Quaday, and Roseanna Ander. 1996. "Guns in Young Hands: A Survey of Urban Teenagers' Attitudes and Behaviors Related to Handgun Violence.” Journal of Trauma, Vol. 41, No. 5, pp. 794-798.

Bernstein, Maxine. 2014. "Jared Padgett Wrote About Killing Classmates in Journal." The Oregonian, June 13. Available at:

http://www.oregonlive.com/gresham/index.ssf/2014/06/oregon_school_shooting_gunman 1.html.

Bertrand, Marianne, Esther Duflo, and Sendhil Mullainathan. 2004. "How Much Should We Trust Differences-in-Differences Estimates?” Quarterly Journal of Economics, Vol. 119, No. 1, pp. 249-275. 
Bryk, Anthony and Yeow Meng Thum. 1989. "The Effects of High School Organization on Dropping Out: An Exploratory Investigation.” American Educational Research Journal, Vol. 26, No. 3, pp. 353-383.

Carpenter, Christopher and Mark Stehr. 2008. "The Effects of Mandatory Seatbelt Laws on Seatbelt Use, Motor Vehicle Fatalities, and Crash-Related Injuries among Youths." Journal of Health Economics, Vol. 27, No. 3, pp. 642-662.

Cawley, John, Chad Meyerhoefer, and David Newhouse. 2007. "The Impact of State Physical Education Requirements on Youth Physical Activity and Overweight." Health Economics, Vol. 16, No. 12, pp. 1287-1301.

Chandler, Dana, Steven Levitt, and John List. 2011. "Predicting and Preventing Shootings among At-Risk Youth.” American Economic Review: Papers and Proceedings, Vol. 101, No. 3, pp. 288-292.

Cheng, Cheng and Mark Hoekstra. 2013. "Does Strengthening Self-Defense Law Deter Crime or Escalate Violence? Evidence from Expansions to Castle Doctrine.” Journal of Human Resources, Vol. 48, No. 3, pp. 821-854.

Christakis, Erika and Nicholas Christakis. 2012. “Ohio School Shooting: Are Parents to Blame?” TIME, February 28. Available at: http://ideas.time.com/2012/02/28/ohio-school-shooting-why-parents-are-to-blame/.

Columbine-angels.com. 2015. "School Violence Around the World.” Available at: http://www.columbine-angels.com/School_Violence.htm.

Cook, Philip and Jens Ludwig. 2004. "Does Gun Prevalence Affect Teen Gun Carrying After All?" Criminology, Vol. 42, No. 1.

Copeland, Larry. 2014. "Report: School Shootings Often Involve Guns from Home.” USA Today, December 10. Available at: http://www.usatoday.com/story/news/nation/2014/12/09/report-says-guns-in-schoolshootings-often-come-from-home/20143495/.

Crimesider staff. 2012. "Report: Chardon High School Shooting Suspect TJ Lane May Have Used Grandfather's Gun in Attack." CBS News, February 29. Available at: http://www.cbsnews.com/news/report-chardon-high-school-shooting-suspect-tj-lanemay-have-used-grandfathers-gun-in-attack/.

Cummings, Peter, David Grossman, Frederick Rivara, and Thomas Koepsell. 1997. "State Gun Safe Storage Laws and Child Mortality Due to Firearms.” Journal of the American Medical Association, Vol. 278, No. 13, pp. 1084-1086.

Dee, Thomas. 1998. "Reconsidering the Effects of Seat Belt Laws and their Enforcement Status." 
Accident Analysis and Prevention, Vol. 30, No. 1, pp. 1-10.

DeSimone, Jeffrey, Sara Markowitz, and Jing Xu. 2013. “Child Access Prevention Laws and Nonfatal Gun Injuries.” Southern Economic Journal, Vol. 80, No. 1, pp. 5-25.

Dinkes, Rachel, Jana Kemp, Katrina Baum, and Thomas Snyder. 2009. Indicators of School Crime and Safety: 2008. National Center for Education Statistics, Institute of Education Sciences, U.S. Department of Education, and Bureau of Justice Statistics, Office of Justice Programs, U.S. Department of Justice. Washington, D.C.

Dolak, Kevin, Christina Ng, and Barbara Lowe. 2012. "Ohio High School Shooting: Student Suspect to Be Tried as Adult." $A B C$ News, February 29. Available at: http://abcnews.go.com/US/ohio-high-school-shooting-prosecutors-tj-laneadult/story?id=15814303.

Doll, Jonathan. In Press. Ending School Shootings: A Guide to Prevention and Action.

Donohue, John and Ian Ayres. 2009. "More Guns, Less Crime Fails Again: The Latest Evidence from 1977-2006." Faculty Scholarship Series. Paper 47. Available at: http://digitalcommons.law.yale.edu/fss_papers/47/?utm_source=digitalcommons.law.yale .edu\%2Ffss_papers\%2F47\&utm_medium=PDF\&utm_campaign=PDFCoverPages.

Emmert, Amanda and Alan Lizotte. 2015. "Weapon Carrying and Use Among Juveniles.” In the Handbook of Juvenile Delinquency and Juvenile Justice (eds. Marvin Krohn and Jodi Lane). Hoboken, New Jersey: John Wiley and Sons, Inc.

Everytown.org. 2015a. “Analysis of School Shootings.” Available at: http://everytown.org/documents/2014/10/analysis-of-school-shootings.pdf.

Everytown.org. 2015b. "School Shootings in America Since Sandy Hook.” Available at: http://everytown.org/article/schoolshootings/.

FBI. 2002. “The School Shooter: A Quick Reference Guide.” Available at: http://www.broward.edu/safety/Documents/FBITheSchoolShooterAQuickReferenceGuid e.pdf.

Grogger, Jeffrey. 1997. “Local Violence and Educational Attainment.” Journal of Human Resources, Vol. 32, No. 4, pp. 659-682.

Grossman, Richard and Stephen Lee. 2008. "May Issue Versus Shall Issue: Explaining the Pattern of Concealed-Carry Handgun Laws, 1960-2001." Contemporary Economic Policy, Vol. 26, No. 2, pp. 198-206.

Hansen, Benjamin, Daniel I. Rees, and Joseph J. Sabia. 2013. "Cigarette Taxes and How Youths Obtain Cigarettes." National Tax Journal, Vol. 66, No. 2, pp. 371-394. 
Hansen, Benjamin, Joseph J. Sabia, and Daniel I. Rees. 2015. "Cigarette Taxes and Youth Smoking: Updated Estimates Using YBRS Data." NBER Working Paper No. 21311.

Harmacinski, Jill. 2013. “Arraigned on Gun Charges.” Eagle Tribune, October 1. Available at: http://www.eagletribune.com/news/arraigned-on-gun-charges/article_88ea251e-68c35c67-9793-22dda607c5fc.html.

Hemenway, David, Deborah Prothrow-Stith, Jack Bergstein, Roseanna Ander, and Bruce Kennedy. 1996. "Gun Carrying among Adolescents.” Law and Contemporary Problems, Vol. 59, No. 1, pp. 39-53.

Hemenway, David, Mary Vriniotis, Rene Johnson, Matthew Miller, and Deborah Azrael. 2011. "Gun Carrying by High School Students in Boston, MA: Does Overestimation of Peer Gun Carrying Matter?” Journal of Adolescence, Vol. 34, No. 5, pp. 997-1003

Hinkston, Mark. 2012. "Wisconsin's Concealed Carry Law: Protecting Persons and Property." Wisconsin Lawer, Vol. 85, No. 7. Available at: http://www.wisbar.org/newspublications/wisconsinlawyer/pages/article.aspx?Volume $=85$ \&Issue $=7 \&$ ArticleID $=8710$.

Klein, Jessie. 2012. The Bully Society: School Shootings and the Crisis of Bullying in America's Schools. New York City, New York: New York University Press.

Konnikova, Maria. 2014. "Is There a Link between Mental Health and Gun Violence?" The New Yorker, November 19. Available at: http://www.newyorker.com/science/maria-konnikova/almost-link-mental-health-gunviolence.

Kuo, Tzu-Chun. 2012. "Evaluating Californian Under-Age Drunk Driving Laws: Endogenous Policy Lags.” Journal of Applied Econometrics, Vol. 27, No. 7, pp. 1100-1115.

Lacoe, Johanna. 2013. “Too Scared to Learn? The Academic Consequences of Feeling Unsafe at School.” Institute for Education and Social Policy Working Paper No. 02-13.

Lang, Matthew. 2013. "The Impact of Mental Health Insurance Laws on State Suicide Rates." Health Economics, Vol. 22, No. 1, pp. 73-88.

Laub, John and Janet Lauritsen. 1998. "Interdependence of School Violence with Neighborhood and Family Conditions." In Violence in American Schools: A New Perspective (eds. Delbert Elliot, Beatrix Hamburg, and Kirk Williams). New York City, New York: Cambridge University Press.

Law Center to Prevent Gun Violence. 2013. "Child Access Prevention Policy Summary.” Available at: http://smartgunlaws.org/child-access-prevention-policy-summary/. 
Lieberman, Joseph. 2008. School Shootings: What Every Parent and Educator Needs to Know to Protect Our Children. New York City, New York: Kensington Publishing Corp.

Lithwick, Dahlia. 2015. "Leave Your Gun Out, Go to Jail." Slate, October 12. Available at: http://www.slate.com/articles/news_and_politics/jurisprudence/2015/10/gun_accidents_w hy_are_parents_who_leave_loaded_weapons_lying_around_never.html.

Lizotte, Alan, Gregory Howard, Marvin Krohn, and Terence Thornberry. 1997. "Patterns of Illegal Gun Carrying Among Urban Males.” Valparaiso University Law Review, Vol. 31, No. 2, pp. 375-393.

Lizotte, Alan, James Tesoriero, Terence Thornberry, and Marvin Krohn. 1994. "Patterns of Adolescent Firearms Ownership and Use.” Justice Quarterly, Vol. 11, No. 1, pp. 51-74.

Lott, John, Jr. and John Whitley. 2001. "Safe-Storage Gun Laws: Accidental Deaths, Suicides, and Crime.” Journal of Law and Economics, Vol. 44, No. S2, pp. 659-689.

Ludwig, Jens. 1998. "Concealed-Gun-Carrying Laws and Violent Crime: Evidence from State Panel Data.” International Review of Law and Economics, Vol. 18, No. 3, pp. 239-254.

Markowitz, Sara, Robert Kaestner, and Michael Grossman. 2005. "An Investigation of the Effects of Alcohol Consumption and Alcohol Prices on Youth Risky Sexual Behaviors." American Economic Review, Vol. 95, No. 2, pp. 263-266.

Marvell, Thomas. 2001. “The Impact of Banning Juvenile Gun Possession.” Journal of Law and Economics, Vol. 44, No. S2, pp. 691-713.

Mayer, Matthew and Peter Leone. 1999. "A Structural Analysis of School Violence and Disruption: Implications for Creating Safer Schools." Education and Treatment of Children, Vol. 22, No. 3, pp. 333-356.

McClellan, Chandler and Erdal Tekin. 2012. "Stand Your Ground Laws, Homicides, and Injuries.” NBER Working Paper No. 18187.

Midlarsky, Elizabeth and Helen Marie Klain. 2005. “A History of Violence in Schools.” In Violence in Schools: Cross-National and Cross-Cultural Perspectives (eds. Florence Denmark, Herbert Krass, Robert Wesner, Elizabeth Midlarsky, and Uwe Gielen). New York, New York: Springer Science+Business Media, Inc.

Mustard, David. 2001. “The Impact of Gun Laws on Police Deaths.” Journal of Law and Economics, Vol. 44, No. S2, pp. 635-657.

National School Safety and Security Services. 2010. "School Associated Violent Deaths and School Shootings.” Available at: http://www.schoolsecurity.org/trends/violent-deaths-and-school-shootings/. 
Okoro, Catherine, David Nelson, James Mercy, Lina Balluz, Ale Crosby, and Ali Mokdad. 2005. "Prevalence of Household Firearms and Firearm-Storage Practices in the 50 States and the District of Columbia: Findings from the Behavioral Risk Factor Surveillance System, 2002.” Pediatrics, Vol. 116, No. 3, pp. e370-e376.

Patel, Sejal. 2014. “Kids and Gun Safety.” Children’s Rights Litigation, American Bar Association. Available at:

https://apps.americanbar.org/litigation/committees/childrights/content/articles/spring2014 -0414-kids-gun-safety.html.

Peters, Justin. 2013a. “California’s Strict New Access Prevention Law Won’t Do Much to Stop Child Shooting Deaths.” Slate, October 15. Available at:

http://www.slate.com/blogs/crime/2013/10/15/firearm_safe_and_responsible_access_act california_s_strict_new_access_prevention.html.

Peters, Justin, 2013b. “194 Children Have Been Shot and Killed in America in 2013. This Has to Stop.” Slate, December 10. Available at:

http://www.slate.com/blogs/crime/2013/12/10/child_shootings_mother_jones_194_child_ shooting deaths in 2013 show that.html

Poutvaara, Panu and Olli Ropponen. 2010. "School Shootings and Student Performance.” IZA Discussion Paper No. 5009.

Prickett, Kate C., Alexa Martin-Storey, and Robert Crosnoe. 2014. "State Firearm Laws, Firearm Ownership, and Safety Practices Among Families of Preschool-Aged Children.” American Journal of Public Health, Vol. 104, No. 6, pp. 1080-1086.

Ripski, Michael and Anne Gregory. 2009. "Unfair, Unsafe, and Unwelcome: Do School Students' Perceptions of Unfairness, Hostility, and Victimization in School Predict Engagement and Achievement?” Journal of School Violence, Vol. 8, No. 4, pp. 355-375.

Rocque, Michael. 2012. "Exploring School Rampage Shootings: Research, Theory, and Policy.” Social Science Journal, Vol. 49, No. 3, pp. 304-313.

Ruggles, Kelly and Sonali Rajan. 2014. "Gun Possession among American Youth: A DiscoveryBased Approach to Understand Gun Violence.” PLoS ONE, Vol. 9, No. 11, e111893.

Ruhm, Christopher. 1996. "Alcohol Policies and Highway Vehicle Fatalities." Journal of Health Economics, Vol. 15, No. 4, pp. 435-465.

Rumberger, Russell. 1995. "Dropping Out of Middle School: A Multilevel Analysis of Students and Schools.” American Educational Research Journal, Vol. 32, No. 3, pp. 583-625.

Sabia, Joseph J. and Brittany Bass. 2015. “Do Anti-Bullying Laws Reduce Youth Violence?” IZA Discussion Paper No. 9201.

Sabia, Joseph J., M. Melinda Pitts, and Laura Argys. 2014. "Do Minimum Wages Really 
Increase Youth Drinking and Drunk Driving?" Federal Reserve Bank of Atlanta Working Paper No. 2014-20.

Said, Stephan. 2015. "The Cause of School Shootings: We're Missing the Mark." Huffington Post, October 9. Available at:

http://www.huffingtonpost.com/stephan-said/the-cause-of-school-shoot_b_8268078.html.

Saukkonen, Suvi, Taina Laajasalo, Markus Jokela, Janne Kivivuori, Venla Salmi, and Eeva Aronen. "Weapon Carrying and Psychopathic-like Features in a Population-based Sample of Finnish Adolescents." Forthcoming at European Child and Adolescent Psychiatry.

Schuster, Mark, Todd Franke, Amy Bastian, Sinaroth Sor, and Neal Halfon. 2000. "Firearm Storage Patterns in US Homes With Children.” American Journal of Public Health, Vol. 90, No. 4, pp. 588-594.

Shaffer, Rachel. 1999. “Child Access Prevention Laws: Keeping Guns Out of Our Children's Hands.” Fordham Urban Law Journal, Vol. 27, No. 6, pp. 1985-2024.

Simon, Thomas, Alex Crosby, and Linda Dahlberg. 1999. "Students Who Carry Weapons to High School." Journal of Adolescent Health, Vol. 24, No. 5, pp. 340-348.

Slauson, Tyler. 2014. "Search Warrant: Oregon High School Shooter Took Gun from His Brother." Q13 Fox, June 19. Available at:

http://q13fox.com/2014/06/19/search-warrant-oregon-high-school-shooter-took-gunfrom-his-brother/.

Stoller, Gary and Oren Dorell. 2012. "Classmate Says Adam Lanza Attended Sandy Hook School.” USA Today, December 19. Available at: http://www.usatoday.com/story/news/2012/12/18/adam-lanza-sandy-hookstudent/1777525/.

Stoptheshootings.org. 2013. "List of School Shootings.” Available at: http://www.stoptheshootings.org.

Taylor, Benjamin and Jing Li. 2015. "Do Fewer Guns Lead to Less Crime? Evidence from Australia." International Review of Law and Economics, Vol. 42, pp. 72-78.

United States Government Accountability Office. 2012. "States' Laws and Requirements for Concealed Carry Permits Vary across the Nation." Report to Congressional Requesters GAO-12-717. Available at: http://www.gao.gov/assets/600/592552.pdf.

USA Carry. 2015. "Concealed Carry Permit Reciprocity Maps." Available at: http://www.usacarry.com/concealed_carry_permit_reciprocity_maps.html.

Van Fleet, David and Ella Van Fleet. 2010. The Violence Volcano: Reducing the Threat of 
Workplace Violence. Charlotte, North Carolina: Information Age Publishing.

Vartabedian, Ralph. 2014. "Related Story: Gun Violence at U.S. Schools Continues to Grow Sharply." Los Angeles Times, June 11. Available at:

http://www.latimes.com/nation/nationnow/la-na-nn-gun-violence-schools-20140610story.html.

Vaughn, Michael, Brian Perron, Arnelyn Abdon, Rene Olate, Ralph Groom, and Li-Tzy Wu. 2012. "Correlates of Handgun Carrying Among Adolescents in the United States." Journal of Interpersonal Violence, Vol. 27, No. 10, pp. 2003-2021.

Violence Policy Center. 2001. “Where'd They Get Their Guns?” Available at: https://www.vpc.org/studies/wgunint.htm.

Warner, Beth, Mark Weist, and Amy Krulak. 1999. "Risk Factors for School Violence." Urban Education, Vol. 34, No. 1, pp. 52-68.

Webster, Daniel and Marc Starnes. 2000. "Reexamining the Association Between Child Access Prevention Gun Laws and Unintentional Shooting Deaths of Children.” Pediatrics, Vol. 106, No. 6, pp. 1466-1469.

Webster, Daniel, Jon Vernick, April Zeoli, and Jennifer Manganello. 2004. “Association Between Youth-Focused Firearm Laws and Youth Suicides.” Journal of the American Medical Association, Vol. 292, No. 5, pp. 594-601.

Wood, Daniel. 2001. "Where School Shooters Get Their Guns.” The Christian Science Monitor, March 12. Available at: http://www.csmonitor.com/2001/0312/p1s3.html.

Young, Colin. 2012. "Dorchester Man Charged after Two Loaded Guns are found in his Apartment." Boston.com, November 8. Available at: http://www.boston.com/2012/11/08/tom/Y1OqFJxuaVWh87w63OlrEM/story.html. 
Figure 1. Outcomes in the National YRBS

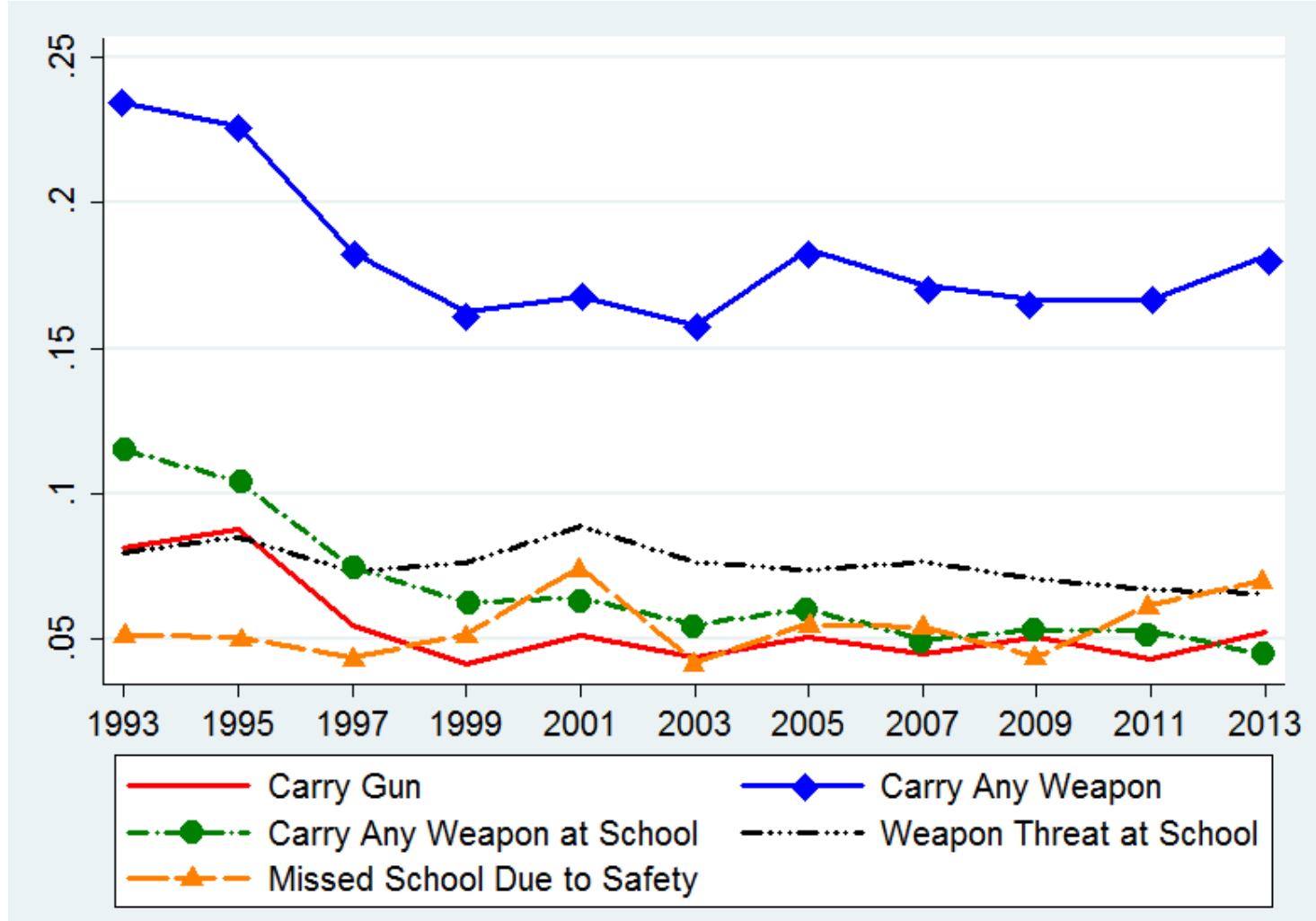

Notes: Weighted estimates are obtained using YRBS data from 1991 to 2013. 
Figure 2. Outcomes in the State YRBS

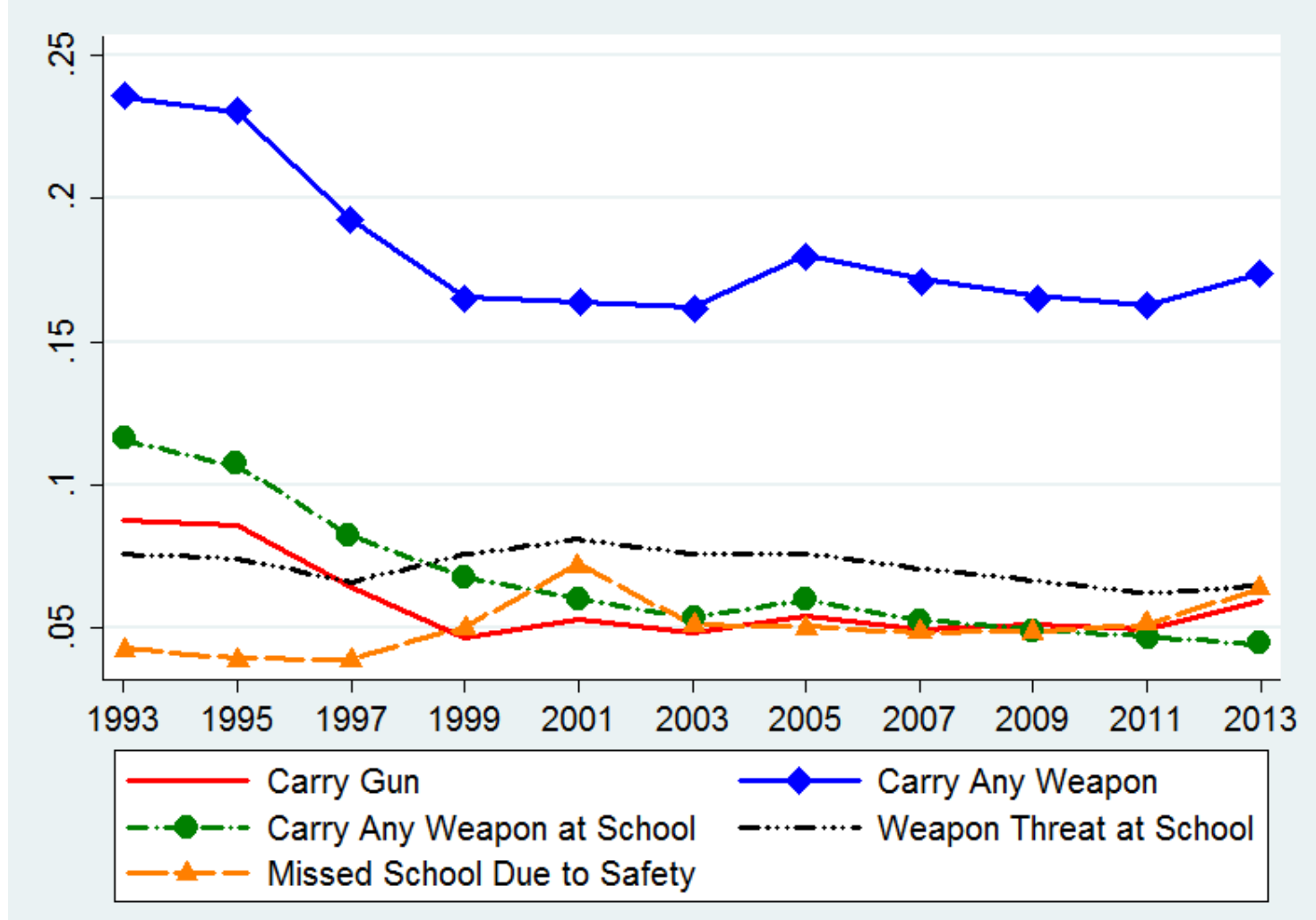

Notes: Weighted estimates are obtained using YRBS data from 1991 to 2013. 
Table 1. Child Access Prevention Laws

\begin{tabular}{lcc} 
& Effective Date & Type of CAP Law \\
\hline California & January 1, 1992 & Negligent Storage \\
Colorado & October 13, 2000 & Reckless Endangerment \\
Connecticut & October 1,1990 & Negligent Storage \\
Delaware & July 2, 1998 & Reckless Endangerment \\
District of Columbia & January 28, 2009 & Negligent Storage \\
Florida & October 1,1989 & Negligent Storage \\
Georgia & May 1, 1994 & Reckless Endangerment \\
Hawaii & July 1, 1992 & Negligent Storage \\
Illinois & January 1, 2000 & Negligent Storage \\
Indiana & March 7, 1994 & Reckless Endangerment \\
Iowa & April 5, 1990 & Negligent Storage \\
Kentucky & July 15, 1994 & Reckless Endangerment \\
Maryland & April 1, 1992 & Negligent Storage \\
Massachusetts & October 21, 1998 & Negligent Storage \\
Minnesota & May 20, 1993 & Negligent Storage \\
Mississippi & July 2, 1994 & Reckless Endangerment \\
Missouri & September 28, 1981 & Reckless Endangerment \\
Nevada & July 1, 1995 & Reckless Endangerment \\
New Hampshire & January 1, 2001 & Negligent Storage \\
New Jersey & January 17, 1992 & Negligent Storage \\
North Carolina & December 1, 1993 & Negligent Storage \\
Oklahoma & July 7, 1993 & Reckless Endangerment \\
Rhode Island & July 1, 1995 & Negligent Storage \\
Tennessee & July 1, 1994 & Reckless Endangerment \\
Texas & September 1, 1995 & Negligent Storage \\
Utah & October 21, 1993 & Reckless Endangerment \\
Virginia & July 1, 1992 & Reckless Endangerment \\
Wisconsin & March 1, 1992 & Reckless Endangerment \\
\hline
\end{tabular}

Notes: States for which YRBS data (1993-2013) are available before and after a CAP law went into effect are denoted in italicized font. Data on CAP laws were obtained from the Law Center to Prevent Gun Violence (2013). 
Table 2. Descriptive Statistics for YRBS Analysis, 1993-2013

\begin{tabular}{|c|c|c|c|c|}
\hline & CAP Law $=1^{\mathrm{a}}$ & CAP Law $=0$ & Full Sample & Description \\
\hline \multicolumn{5}{|l|}{ Dependent Variables } \\
\hline Carry Gun & $\begin{array}{l}.056 \\
(.230)\end{array}$ & $\begin{array}{l}.053 \\
(.225)\end{array}$ & $\begin{array}{l}.055 \\
(.228)\end{array}$ & $=1$ if respondent carried a gun in the past 30 days, $=$ \\
\hline Carry Any Weapon & $\begin{array}{l}.181 \\
(.385)\end{array}$ & $\begin{array}{l}.169 \\
(.375)\end{array}$ & $\begin{array}{l}.176 \\
(.381)\end{array}$ & $\begin{array}{l}=1 \text { if respondent carried a weapon such as a gun, kni } \\
30 \text { days, }=0 \text { otherwise }\end{array}$ \\
\hline Carry Any Weapon at School & $\begin{array}{l}.059 \\
(.236)\end{array}$ & $\begin{array}{c}.062 \\
(.241)\end{array}$ & $\begin{array}{c}.060 \\
(.238)\end{array}$ & $\begin{array}{l}=1 \text { if respondent carried a weapon such as a gun, kni } \\
\text { property in the past } 30 \text { days, }=0 \text { otherwise }\end{array}$ \\
\hline Weapon Threat at School & $\begin{array}{l}.071 \\
(.257)\end{array}$ & $\begin{array}{c}.072 \\
(.258)\end{array}$ & $\begin{array}{l}.071 \\
(.257)\end{array}$ & $\begin{array}{l}=1 \text { if respondent was threatened or injured with a we } \\
\text { knife, or club on school property in the past } 12 \text { month }\end{array}$ \\
\hline Missed School Due to Safety & $\begin{array}{l}.054 \\
(.226)\end{array}$ & $\begin{array}{l}.051 \\
(.219)\end{array}$ & $\begin{array}{l}.053 \\
(.224)\end{array}$ & $\begin{array}{l}=1 \text { if respondent missed school in the past } 30 \text { days } d t \\
\text { school or on the way to or from school, = } 0 \text { otherwise }\end{array}$ \\
\hline \multicolumn{5}{|l|}{ Independent Variables } \\
\hline White & $\begin{array}{l}.829 \\
(.377)\end{array}$ & $\begin{array}{l}.830 \\
(.376)\end{array}$ & $\begin{array}{l}.829 \\
(.376)\end{array}$ & $=1$ if respondent is white, $=0$ otherwise \\
\hline Black & $\begin{array}{l}.097 \\
(.295)\end{array}$ & $\begin{array}{l}.110 \\
(.313)\end{array}$ & $\begin{array}{l}.102 \\
(.303)\end{array}$ & $=1$ if respondent is black, $=0$ otherwise \\
\hline Other Race & $\begin{array}{l}.075 \\
(.263)\end{array}$ & $\begin{array}{l}.060 \\
(.238)\end{array}$ & $\begin{array}{c}.068 \\
(.253)\end{array}$ & $=1$ if respondent is not white or black, $=0$ otherwise \\
\hline Age 12 & $\begin{array}{l}.001 \\
(.032)\end{array}$ & $\begin{array}{c}.001 \\
(.030)\end{array}$ & $\begin{array}{c}.001 \\
(.031)\end{array}$ & $=1$ if respondent is 12 years old, $=0$ otherwise \\
\hline Age 13 & $\begin{array}{l}.002 \\
(.039)\end{array}$ & $\begin{array}{l}.006 \\
(.076)\end{array}$ & $\begin{array}{l}.003 \\
(.057)\end{array}$ & $=1$ if respondent is 13 years old, = 0 otherwise \\
\hline Age 14 & $\begin{array}{l}.102 \\
(.302)\end{array}$ & $\begin{array}{l}.116 \\
(.321)\end{array}$ & $\begin{array}{l}.108 \\
(.310)\end{array}$ & $=1$ if respondent is 14 years old, $=0$ otherwise \\
\hline Age 15 & .250 & $\begin{array}{l}.254 \\
(.435)\end{array}$ & $\begin{array}{l}.251 \\
(.434)\end{array}$ & $=1$ if respondent is 15 years old, $=0$ otherwise \\
\hline Age 16 & $\begin{array}{l}.266 \\
(.442)\end{array}$ & $\begin{array}{l}.266 \\
(.442)\end{array}$ & $\begin{array}{l}.266 \\
(.442)\end{array}$ & $=1$ if respondent is 16 years old, $=0$ otherwise \\
\hline Age 17 & $\begin{array}{l}.244 \\
(.429)\end{array}$ & $\begin{array}{l}.235 \\
(.424)\end{array}$ & $\begin{array}{l}.240 \\
(.427)\end{array}$ & $=1$ if respondent is 17 years old, $=0$ otherwise \\
\hline Age $18+$ & $\begin{array}{l}.137 \\
(.343)\end{array}$ & $\begin{array}{l}.122 \\
(.327)\end{array}$ & $\begin{array}{l}.130 \\
(.337)\end{array}$ & $=1$ if respondent is $18+$ years old, $=0$ otherwise \\
\hline
\end{tabular}




\begin{tabular}{|c|c|c|c|}
\hline Grade 8 & $\begin{array}{c}.000 \\
(.000)\end{array}$ & $\begin{array}{c}.005 \\
(.067)\end{array}$ & $\begin{array}{c}.002 \\
(.044)\end{array}$ \\
\hline \multirow[t]{2}{*}{ Grade 9} & .268 & .265 & .267 \\
\hline & $(.443)$ & $(.442)$ & $(.442)$ \\
\hline \multirow[t]{2}{*}{ Grade 10} & .260 & .270 & .264 \\
\hline & $(.439)$ & $(.444)$ & $(.441)$ \\
\hline \multirow[t]{2}{*}{ Grade 11} & .249 & .243 & .246 \\
\hline & $(.432)$ & $(.429)$ & $(.431)$ \\
\hline \multirow[t]{2}{*}{ Grade 12} & .221 & .215 & .218 \\
\hline & $(.415)$ & $(.411)$ & $(.413)$ \\
\hline \multirow[t]{2}{*}{ Male } & .504 & .506 & .505 \\
\hline & $(.500)$ & $(.500)$ & $(.500)$ \\
\hline \multirow[t]{2}{*}{$\%$ Black } & .311 & .300 & .306 \\
\hline & $(.048)$ & $(.064)$ & $(.056)$ \\
\hline \multirow[t]{2}{*}{ Mean Age } & 41.0 & 40.6 & 40.8 \\
\hline & $(1.04)$ & $(.918)$ & $(1.02)$ \\
\hline \multirow[t]{2}{*}{$\%$ Male } & .501 & .501 & .501 \\
\hline & $(.003)$ & $(.003)$ & $(.003)$ \\
\hline \multirow[t]{2}{*}{ Unemployment Rate } & .065 & .063 & .064 \\
\hline & $(.022)$ & $(.020)$ & $(.021)$ \\
\hline \multirow[t]{2}{*}{ Per Capita Income } & 42,694 & 42,104 & 42,447 \\
\hline & $(6,302)$ & $(7,549)$ & $(6,857)$ \\
\hline \multirow[t]{2}{*}{ \% Bachelor's Degree } & .290 & .271 & .282 \\
\hline & $(.056)$ & $(.053)$ & $(.055)$ \\
\hline \multirow[t]{2}{*}{ Student-Teacher Ratio } & 16.0 & 14.7 & 15.4 \\
\hline & $(2.99)$ & $(2.70)$ & $(2.94)$ \\
\hline \multirow[t]{2}{*}{ School Lunch Program } & .099 & .097 & .098 \\
\hline & $(.021)$ & $(.015)$ & $(.018)$ \\
\hline \multirow[t]{2}{*}{ Teacher Salary } & 57,623 & 62,532 & 59,673 \\
\hline & $(9,004)$ & $(10,364)$ & $(9,896)$ \\
\hline \multirow[t]{2}{*}{ Zero Tolerance Law } & .961 & .921 & .944 \\
\hline & $(.182)$ & $(.261)$ & $(.219)$ \\
\hline \multirow[t]{2}{*}{ Anti-Bullying Law } & .397 & .194 & .312 \\
\hline & $(.479)$ & $(.381)$ & $(.452)$ \\
\hline \multirow[t]{2}{*}{ Police Expenditures } & 306 & 313 & 309 \\
\hline & $(77.0)$ & (110) & $(92.3)$ \\
\hline
\end{tabular}

$=1$ if respondent is in grade $8,=0$ otherwise

$=1$ if respondent is in grade $9,=0$ otherwise

$=1$ if respondent is in grade $10,=0$ otherwise

$=1$ if respondent is in grade $11,=0$ otherwise

$=1$ if respondent is in grade $12,=0$ otherwise

$=1$ if respondent is male, $=0$ otherwise

Percent of the state population that is black

State mean age

Percent of the state population this is male

State unemployment rate

State real income per capita (2013 dollars)

Percent of the state population with a bachelor's degree

Average Student to Teacher Ratio

National School Lunch Participation Rate

Average Teacher Salary (2013 dollars)

= 1 if state has a zero tolerance school violence law, $=0$ otherwise

$=1$ if state has an anti-bullying law, $=0$ otherwise

State police expenditures per capita (2013 dollars) 


\begin{tabular}{|c|c|c|c|c|}
\hline Police Employment & $\begin{array}{c}2.20 \\
(.314)\end{array}$ & $\begin{array}{c}2.74 \\
(.993)\end{array}$ & $\begin{array}{c}2.43 \\
(.733)\end{array}$ & State police employees per 1,000 population \\
\hline Property Crime & $\begin{array}{l}1,018 \\
(339)\end{array}$ & $\begin{array}{c}774 \\
(320)\end{array}$ & $\begin{array}{c}907 \\
(352)\end{array}$ & State adult property crime arrests per 100,000 population \\
\hline Violent Crime & $\begin{array}{l}449 \\
(226)\end{array}$ & $\begin{array}{l}326 \\
(167)\end{array}$ & $\begin{array}{l}393 \\
(210)\end{array}$ & State adult violent crime arrests per 100,000 population \\
\hline Democrat & $\begin{array}{c}.406 \\
(.491)\end{array}$ & $\begin{array}{c}.453 \\
(.498)\end{array}$ & $\begin{array}{c}.425 \\
(.494)\end{array}$ & $=1$ if state has a democratic governor, $=0$ otherwise \\
\hline Shall Issue Law & $\begin{array}{l}.600 \\
(.490)\end{array}$ & $\begin{array}{l}.435 \\
(.496)\end{array}$ & $\begin{array}{l}.531 \\
(.499)\end{array}$ & $=1$ if state has a shall issue gun law, $=0$ otherwise \\
\hline Stand Your Ground Law & $\begin{array}{l}.304 \\
(.449)\end{array}$ & $\begin{array}{l}.186 \\
(.388)\end{array}$ & $\begin{array}{l}.255 \\
(.429)\end{array}$ & $=1$ if state has a stand your ground gun law, $=0$ otherwise \\
\hline Mental Health Parity Law & $\begin{array}{l}.524 \\
(.499)\end{array}$ & $\begin{array}{l}.502 \\
(.497)\end{array}$ & $\begin{array}{l}.515 \\
(.498)\end{array}$ & $=1$ if state has a mental health parity law, $=0$ otherwise \\
\hline Beer Tax & $\begin{array}{l}.292 \\
(.195)\end{array}$ & $\begin{array}{c}.271 \\
(.221)\end{array}$ & $\begin{array}{l}.283 \\
(.207)\end{array}$ & Beer taxes (2013 dollar) \\
\hline $\mathrm{N}$ & 508,614 & 541,900 & $1,050,514$ & \\
\hline
\end{tabular}

${ }^{\mathrm{a}}$ If a CAP law is in effect for any portion of the year, the observation is included in this column.

Notes: Weighted means presented along with standard deviations. 
Table 3. CAP Laws, Gun Carrying, and School Safety

$\begin{array}{ccccc} & \text { Carry Any } & \text { Carry Any } & \text { Weapon Threat } & \text { Missed School } \\ \text { Carry Gun } & \text { Weapon } & \text { Weapon at School } & \text { at School } & \text { Due to Safety }\end{array}$

Panel I: Full sample

\begin{tabular}{|c|c|c|c|c|c|}
\hline \multirow[b]{2}{*}{ CAP Law } & & & & & \\
\hline & $\begin{array}{l}-.007 * \\
(.004)\end{array}$ & $\begin{array}{l}-.016^{*} \\
(.010)\end{array}$ & $\begin{array}{l}-.005 \\
(.005)\end{array}$ & $\begin{array}{c}-.013 * * \\
(.006)\end{array}$ & $\begin{array}{l}-.006 \\
(.007)\end{array}$ \\
\hline $\mathrm{N}$ & 776,636 & 919,228 & $1,020,057$ & $1,024,301$ & $1,050,514$ \\
\hline \multirow[b]{2}{*}{ CAP Law } & \multicolumn{5}{|c|}{ Panel II: Students under age 18} \\
\hline & $\begin{array}{l}-.009 * \\
(.005)\end{array}$ & $\begin{array}{l}-.019 * \\
(.010)\end{array}$ & $\begin{array}{l}-.006 \\
(.006)\end{array}$ & $\begin{array}{c}-.016 * * * \\
(.005)\end{array}$ & $\begin{array}{l}-.010 \\
(.007)\end{array}$ \\
\hline $\mathrm{N}$ & 672,373 & 799,904 & 889,523 & 892,550 & 916,544 \\
\hline & \multicolumn{5}{|c|}{ Panel III: Students ages 18+ } \\
\hline CAP Law & $\begin{array}{c}.002 \\
(.006)\end{array}$ & $\begin{array}{c}.004 \\
(.019)\end{array}$ & $\begin{array}{c}.002 \\
(.016)\end{array}$ & $\begin{array}{c}.008 \\
(.012)\end{array}$ & $\begin{array}{c}.016 \\
(.011)\end{array}$ \\
\hline $\mathrm{N}$ & 104,263 & 119,320 & 130,534 & 131,751 & 133,970 \\
\hline
\end{tabular}

* Statistically significant at $10 \%$ level; ** at $5 \%$ level; *** at $1 \%$ level.

Notes: Each cell represents marginal effects from a Probit regression based on data from the YRBS for the period 1993-2013. All models control for the covariates listed in Table 2, state fixed effects, year fixed effects, and state-specific linear time trends.

Regressions are weighted using population estimates from the National Cancer Institute's Surveillance Epidemiology and End

Results Program. Standard errors, corrected for clustering at the state level, are in parentheses. 
Table 4. Interactive Effects of CAP Laws and Shall Issue Laws

\begin{tabular}{|c|c|c|c|c|c|}
\hline & Carry Gun & $\begin{array}{c}\text { Carry Any } \\
\text { Weapon }\end{array}$ & $\begin{array}{c}\text { Carry Any } \\
\text { Weapon at School }\end{array}$ & $\begin{array}{c}\text { Weapon Threat } \\
\text { at School }\end{array}$ & $\begin{array}{c}\text { Missed School } \\
\text { Due to Safety }\end{array}$ \\
\hline & \multicolumn{5}{|c|}{ Panel I: Full sample } \\
\hline CAP Law & $\begin{array}{l}.007^{*} \\
(.004)\end{array}$ & $\begin{array}{l}.016^{*} \\
(.010)\end{array}$ & $\begin{array}{l}-.005 \\
(.005)\end{array}$ & $\begin{array}{c}-.013^{* *} \\
(.006)\end{array}$ & $\begin{array}{l}-.006 \\
(.007)\end{array}$ \\
\hline $\begin{array}{l}\text { CAP Law } \\
\quad \text { *Shall Issue }\end{array}$ & $\begin{array}{l}.005 \\
(.005)\end{array}$ & $\begin{array}{l}.003 \\
(.018)\end{array}$ & $\begin{array}{l}-.000 \\
(.007)\end{array}$ & $\begin{array}{l}-.009 \\
(.006)\end{array}$ & $\begin{array}{l}.006 \\
(.006)\end{array}$ \\
\hline \multirow[t]{2}{*}{$\mathrm{N}$} & 776,636 & 919,228 & $1,020,057$ & $1,024,301$ & $1,050,514$ \\
\hline & \multicolumn{5}{|c|}{ Panel II: Students under age 18} \\
\hline CAP Law & $\begin{array}{l}-.009 * \\
(.005)\end{array}$ & $\begin{array}{l}-.019 * \\
(.010)\end{array}$ & $\begin{array}{l}-.006 \\
(.006)\end{array}$ & $\begin{array}{c}-.016^{* * * *} \\
(.005)\end{array}$ & $\begin{array}{l}-.010 \\
(.007)\end{array}$ \\
\hline $\begin{array}{l}\text { CAP Law } \\
\quad \text { *Shall Issue }\end{array}$ & $\begin{array}{l}.008 * \\
(.005)\end{array}$ & $\begin{array}{l}.008 \\
(.017)\end{array}$ & $\begin{array}{c}.003 \\
(.007)\end{array}$ & $\begin{array}{l}-.007 \\
(.005)\end{array}$ & $\begin{array}{c}.008 \\
(.006)\end{array}$ \\
\hline \multirow[t]{2}{*}{$\mathrm{N}$} & 672,373 & 799,904 & 889,523 & 892,550 & 916,544 \\
\hline & \multicolumn{5}{|c|}{ Panel III: Students ages 18+ } \\
\hline CAP Law & $\begin{array}{l}.002 \\
(.006)\end{array}$ & $\begin{array}{c}.004 \\
(.019)\end{array}$ & $\begin{array}{l}.002 \\
(.016)\end{array}$ & $\begin{array}{c}.008 \\
(.012)\end{array}$ & $\begin{array}{c}.016 \\
(.011)\end{array}$ \\
\hline $\begin{array}{l}\text { CAP Law } \\
\quad \text { *Shall Issue }\end{array}$ & $\begin{array}{l}-.014 \\
(.010)\end{array}$ & $\begin{array}{l}-.033 \\
(.027)\end{array}$ & $\begin{array}{l}-.021 \\
(.019)\end{array}$ & $\begin{array}{l}-.023 \\
(.017)\end{array}$ & $\begin{array}{l}-.006 \\
(.012)\end{array}$ \\
\hline $\mathrm{N}$ & 104,263 & 119,320 & 130,534 & 131,751 & 133,970 \\
\hline
\end{tabular}

* Statistically significant at $10 \%$ level; ** at $5 \%$ level; *** at $1 \%$ level.

Notes: Each cell represents marginal effects from a Probit regression based on data from the YRBS for the period 1993-2013. All models control for the covariates listed in Table 2, state fixed effects, year fixed effects, and state-specific linear time trends. Regressions are weighted using population estimates from the National Cancer Institute's Surveillance Epidemiology and End Results Program. Standard errors, corrected for clustering at the state level, are in parentheses. 
Table 5. Examining Heterogeneous Effects by Type of CAP Law

$\begin{array}{ccccc} & \text { Carry Any } & \text { Carry Any } & \text { Weapon Threat } & \text { Missed School } \\ \text { Carry Gun } & \text { Weapon } & \text { Weapon at School } & \text { at School } & \text { Due to Safety }\end{array}$

Panel I: Full sample

\begin{tabular}{|c|c|c|c|c|c|}
\hline Negligent Storage & $\begin{array}{c}-.011^{* *} \\
(.005)\end{array}$ & $\begin{array}{c}-.023 * * \\
(.011)\end{array}$ & $\begin{array}{l}-.006 \\
(.008)\end{array}$ & $\begin{array}{l}-.011 \\
(.007)\end{array}$ & $\begin{array}{l}-.009 \\
(.008)\end{array}$ \\
\hline $\begin{array}{l}\text { Reckless } \\
\text { Endangerment }\end{array}$ & $\begin{array}{l}-.002 \\
(.005)\end{array}$ & $\begin{array}{l}-.007 \\
(.013)\end{array}$ & $\begin{array}{l}-.004 \\
(.006)\end{array}$ & $\begin{array}{c}-.017 * * \\
(.008)\end{array}$ & $\begin{array}{l}-.002 \\
(.009)\end{array}$ \\
\hline $\mathrm{N}$ & 776,636 & 919,228 & $1,020,057$ & $1,024,301$ & $1,050,514$ \\
\hline & \multicolumn{5}{|c|}{ Panel II: Students under age 18} \\
\hline Negligent Storage & $\begin{array}{c}-.014^{* * * *} \\
(.005)\end{array}$ & $\begin{array}{c}-.027 * * * \\
(.010)\end{array}$ & $\begin{array}{l}-.006 \\
(.008)\end{array}$ & $\begin{array}{c}-.015^{* *} \\
(.007)\end{array}$ & $\begin{array}{l}-.014^{*} \\
(.008)\end{array}$ \\
\hline $\begin{array}{l}\text { Reckless } \\
\text { Endangerment }\end{array}$ & $\begin{array}{l}-.002 \\
(.006)\end{array}$ & $\begin{array}{l}-.007 \\
(.013)\end{array}$ & $\begin{array}{l}-.005 \\
(.006)\end{array}$ & $\begin{array}{l}-.018 * \\
(.010)\end{array}$ & $\begin{array}{l}-.002 \\
(.009)\end{array}$ \\
\hline $\mathrm{N}$ & 672,373 & 799,904 & 889,523 & 892,550 & 916,544 \\
\hline \multicolumn{6}{|c|}{ Panel III: Students ages $\mathbf{1 8}^{+}$} \\
\hline Negligent Storage & $\begin{array}{c}.005 \\
(.008)\end{array}$ & $\begin{array}{c}.006 \\
(.021)\end{array}$ & $\begin{array}{l}-.002 \\
(.022)\end{array}$ & $\begin{array}{c}.019 \\
(.012)\end{array}$ & $\begin{array}{c}.022^{*} \\
(0.012)\end{array}$ \\
\hline $\begin{array}{l}\text { Reckless } \\
\text { Endangerment }\end{array}$ & $\begin{array}{l}-.003 \\
(.008)\end{array}$ & $\begin{array}{c}.000 \\
(.025)\end{array}$ & $\begin{array}{c}.006 \\
(.013)\end{array}$ & $\begin{array}{l}-.008 \\
(.011)\end{array}$ & $\begin{array}{c}.007 \\
(.013)\end{array}$ \\
\hline $\mathrm{N}$ & 104,263 & 119,320 & 130,534 & 131,751 & 133,970 \\
\hline
\end{tabular}

* Statistically significant at $10 \%$ level; ** at $5 \%$ level; *** at $1 \%$ level.

Notes: Each cell represents marginal effects from a Probit regression based on data from the YRBS for the period 1993-2013. All models control for the covariates listed in Table 2, state fixed effects, year fixed effects, and state-specific linear time trends. Regressions are weighted using population estimates from the National Cancer Institute's Surveillance Epidemiology and End Results Program. Standard errors, corrected for clustering at the state level, are in parentheses. 
Table 6. CAP Laws, Gun Carrying, and School Safety by Race

$\begin{array}{ccccc} & \text { Carry Any } & \text { Carry Any } & \text { Weapon Threat } & \text { Missed School } \\ \text { Carry Gun } & \text { Weapon } & \text { Weapon at School } & \text { at School } & \text { Due to Safety }\end{array}$

Panel I: White students under age 18

\begin{tabular}{lccccc} 
CAP Law & $-.010^{*}$ & $-.024^{* *}$ & -.006 & $-.017^{* * *}$ & -.008 \\
& $(.005)$ & $(.010)$ & $(.006)$ & $(.006)$ & $(.007)$ \\
$\mathrm{N}$ & & & & \\
& 375,309 & 450,976 & 532,050 & 533,833 & 543,826 \\
& \multicolumn{5}{c}{ Panel II: Black students under age 18 } \\
CAP Law & $-.012^{* *}$ & $-.033^{*}$ & $-.017^{* *}$ & -.016 & .009 \\
& $(.005)$ & $(.020)$ & $(.008)$ & $(.010)$ & $(.010)$ \\
$\mathrm{N}$ & 111,436 & 132,112 & 131,591 & 135,528 & 136,679 \\
\hline
\end{tabular}

* Statistically significant at $10 \%$ level; ** at $5 \%$ level; *** at $1 \%$ level.

Notes: Each cell represents marginal effects from a Probit regression based on data from the YRBS for the period 1993- 2013. All models control for the covariates listed in Table 2, state fixed effects, year fixed effects, and state-specific linear time trends.

Regressions are weighted using population estimates from the National Cancer Institute's Surveillance Epidemiology and End Results Program. Standard errors, corrected for clustering at the state level, are in parentheses. 
Table 7A. Leads and Lags of CAP Laws for Students Under Age 18

\begin{tabular}{lccccc} 
& Carry Gun & $\begin{array}{c}\text { Carry Any } \\
\text { Weapon }\end{array}$ & $\begin{array}{c}\text { Carry Any } \\
\text { Weapon at School }\end{array}$ & $\begin{array}{c}\text { Weapon Threat } \\
\text { at School }\end{array}$ & $\begin{array}{c}\text { Missed School } \\
\text { Due to Safety }\end{array}$ \\
\hline $\begin{array}{l}\text { 2 Years before } \\
\text { CAP Law }\end{array}$ & 0.000 & 0.008 & 0.006 & -0.010 & -0.004 \\
1 Year before & $(0.010)$ & $(0.014)$ & $(0.006)$ & $(0.007)$ & $(0.010)$ \\
CAP Law & -0.001 & -0.002 & 0.019 & 0.004 & $-0.018^{*}$ \\
Year of Law & $(0.010)$ & $(0.023)$ & $(0.013)$ & $(0.011)$ & $(0.009)$ \\
Change & -0.002 & 0.003 & -0.001 & -0.007 & -0.003 \\
1 Year after & $(0.010)$ & $(0.018)$ & $(0.009)$ & $(0.010)$ & $(0.013)$ \\
CAP Law & -0.013 & -0.027 & 0.007 & $-0.019 * * *$ & $-0.022^{* *}$ \\
2+ Years after & $(0.010)$ & $(0.019)$ & $(0.009)$ & $(0.007)$ & $(0.010)$ \\
CAP Law & -0.006 & -0.013 & 0.008 & $-0.024 * * *$ & $-0.026 * *$ \\
N & $(0.009)$ & $(0.019)$ & $(0.010)$ & $(0.008)$ & $(0.010)$ \\
\hline
\end{tabular}

* Statistically significant at $10 \%$ level; ** at $5 \%$ level; *** at $1 \%$ level.

Notes: Each column represents marginal effects from a Probit regression based on data from the YRBS for the period 1993-2013. All models control for the covariates listed in Table 2, state fixed effects, year fixed effects, and state-specific linear time trends.

Regressions are weighted using population estimates from the National Cancer Institute's Surveillance Epidemiology and End Results Program. Standard errors, corrected for clustering at the state level, are in parentheses. 
Table 7B. Leads and Lags of Negligent Storage and Reckless Endangerment Laws for Students Under Age 18

\begin{tabular}{|c|c|c|c|c|c|}
\hline & Carry Gun & $\begin{array}{l}\text { Carry Any } \\
\text { Weapon }\end{array}$ & $\begin{array}{c}\text { Carry Any } \\
\text { Weapon at School }\end{array}$ & $\begin{array}{l}\text { Weapon Threat } \\
\text { at School }\end{array}$ & $\begin{array}{l}\text { Missed School } \\
\text { Due to Safety }\end{array}$ \\
\hline $\begin{array}{l}2 \text { Years before } \\
\text { Negligent Storage }\end{array}$ & $\begin{array}{c}0.003 \\
(0.008)\end{array}$ & $\begin{array}{c}0.010 \\
(0.013)\end{array}$ & $\begin{array}{c}0.002 \\
(0.006)\end{array}$ & $\begin{array}{l}-0.012 \\
(0.007)\end{array}$ & $\begin{array}{l}-0.001 \\
(0.007)\end{array}$ \\
\hline $\begin{array}{l}1 \text { Year before } \\
\text { Negligent Storage }\end{array}$ & $\begin{array}{l}-0.007 \\
(0.011)\end{array}$ & $\begin{array}{l}-0.014 \\
(0.027)\end{array}$ & $\begin{array}{c}0.027 \\
(0.017)\end{array}$ & $\begin{array}{c}0.001 \\
(0.013)\end{array}$ & $\begin{array}{c}-0.029 * * \\
(0.012)\end{array}$ \\
\hline $\begin{array}{l}\text { Year of Negligent } \\
\text { Storage Change }\end{array}$ & $\begin{array}{c}0.003 \\
(0.009)\end{array}$ & $\begin{array}{c}0.003 \\
(0.018)\end{array}$ & $\begin{array}{l}-0.003 \\
(0.009)\end{array}$ & $\begin{array}{l}-0.003 \\
(0.010)\end{array}$ & $\begin{array}{l}-0.008 \\
(0.015)\end{array}$ \\
\hline $\begin{array}{l}1 \text { Year after } \\
\text { Negligent Storage }\end{array}$ & $\begin{array}{c}-0.021^{* *} \\
(0.009)\end{array}$ & $\begin{array}{l}-0.043^{* *} \\
(0.020)\end{array}$ & $\begin{array}{c}0.008 \\
(0.011)\end{array}$ & $\begin{array}{c}-0.023^{* * *} \\
(0.009)\end{array}$ & $\begin{array}{c}-0.032 * * \\
(0.013)\end{array}$ \\
\hline $\begin{array}{l}2+\text { Years after } \\
\text { Negligent Storage }\end{array}$ & $\begin{array}{c}-0.018^{* *} \\
(0.008)\end{array}$ & $\begin{array}{l}-0.032 \\
(0.020)\end{array}$ & $\begin{array}{c}0.013 \\
(0.012)\end{array}$ & $\begin{array}{c}-0.027 * * * \\
(0.009)\end{array}$ & $\begin{array}{c}-0.033^{* *} \\
(0.014)\end{array}$ \\
\hline $\begin{array}{l}2 \text { Years before } \\
\text { Reckless Endangerment }\end{array}$ & $\begin{array}{l}-0.013 \\
(0.020)\end{array}$ & $\begin{array}{c}0.035 \\
(0.041)\end{array}$ & $\begin{array}{c}0.013 \\
(0.021)\end{array}$ & $\begin{array}{l}-0.002 \\
(0.035)\end{array}$ & $\begin{array}{l}-0.025 \\
(0.040)\end{array}$ \\
\hline $\begin{array}{l}1 \text { Year before } \\
\text { Reckless Endangerment }\end{array}$ & $\begin{array}{c}0.011 \\
(0.010)\end{array}$ & $\begin{array}{c}0.046 \\
(0.032)\end{array}$ & $\begin{array}{c}0.007 \\
(0.017)\end{array}$ & $\begin{array}{c}0.019 \\
(0.022)\end{array}$ & $\begin{array}{c}0.022 \\
(0.025)\end{array}$ \\
\hline $\begin{array}{l}\text { Year of Reckless } \\
\text { Endangerment Change }\end{array}$ & $\begin{array}{l}-0.009 \\
(0.018)\end{array}$ & $\begin{array}{c}0.024 \\
(0.039)\end{array}$ & $\begin{array}{l}-0.006 \\
(0.017)\end{array}$ & $\begin{array}{l}-0.019 \\
(0.027)\end{array}$ & $\begin{array}{l}-0.002 \\
(0.028)\end{array}$ \\
\hline $\begin{array}{l}1 \text { Year after } \\
\text { Reckless Endangerment }\end{array}$ & $\begin{array}{l}-0.007 \\
(0.011)\end{array}$ & $\begin{array}{c}0.022 \\
(0.029)\end{array}$ & $\begin{array}{c}0.011 \\
(0.016)\end{array}$ & $\begin{array}{c}-0.001 \\
(0.016)\end{array}$ & $\begin{array}{c}0.018 \\
(0.023)\end{array}$ \\
\hline $\begin{array}{l}2+\text { Years after } \\
\text { Reckless Endangerment }\end{array}$ & $\begin{array}{c}0.005 \\
(0.012)\end{array}$ & $\begin{array}{c}0.036 \\
(0.030)\end{array}$ & $\begin{array}{c}0.001 \\
(0.014)\end{array}$ & $\begin{array}{l}-0.015 \\
(0.017)\end{array}$ & $\begin{array}{l}-0.006 \\
(0.020)\end{array}$ \\
\hline $\mathrm{N}$ & 672,373 & 799,904 & 889,523 & 892,550 & 916,544 \\
\hline
\end{tabular}

* Statistically significant at $10 \%$ level; ** at $5 \%$ level; *** at $1 \%$ level.

Notes: Each column represents marginal effects from a Probit regression based on data from the YRBS for the period 1993-2013. All models control for the covariates listed in Table 2, state fixed effects, year fixed effects, and state-specific linear time trends. Regressions are weighted using population estimates from the National Cancer Institute's Surveillance Epidemiology and End Results Program. Standard errors, corrected for clustering at the state level, are in parentheses. 
Table 8. Falsification Tests for Students Under Age 18

\begin{tabular}{|c|c|c|c|c|}
\hline & Cigarette Use & Marijuana Use & Cocaine Use & Binge Drinking \\
\hline \multirow{2}{*}{ CAP Law } & .002 & .022 & 0.003 & -0.005 \\
\hline & $(.018)$ & $(.021)$ & (0.004) & $(0.012)$ \\
\hline \multirow[t]{2}{*}{$\mathrm{N}$} & 886,205 & 907,613 & 669,815 & 904,960 \\
\hline & Drunk Driving & Seatbelt Use & Helmet Use & Sex Partners \\
\hline \multirow[t]{2}{*}{ CAP Law } & 0.004 & -0.021 & 0.026 & 0.027 \\
\hline & $(0.007)$ & (0.013) & $(0.030)$ & $(0.018)$ \\
\hline \multirow[t]{2}{*}{$\mathrm{N}$} & 883,577 & 890,911 & 548,798 & 782,537 \\
\hline & Exercise & \multicolumn{2}{|c|}{ Diet Pills } & Fruit \\
\hline \multirow[t]{2}{*}{ CAP Law } & 0.011 & \multirow{2}{*}{\multicolumn{2}{|c|}{$\begin{array}{c}-0.008 \\
(0.009)\end{array}$}} & 0.019 \\
\hline & $(0.012)$ & & & $(0.017)$ \\
\hline $\mathrm{N}$ & 492,105 & \multicolumn{2}{|c|}{692,476} & 715,370 \\
\hline
\end{tabular}

Notes: Each column within each panel represents marginal effects from a Probit regression based on data from the YRBS for the period 1993-2013. All models control for the covariates listed in Table 2, state fixed effects, year fixed effects, and state-specific linear time trends. Regressions are weighted using population estimates from the National Cancer Institute’s Surveillance Epidemiology and End Results Program. Standard errors, corrected for clustering at the state level, are in parentheses. 
Table 9. CAP Laws and Gun Carrying by Various Risky Behaviors

\begin{tabular}{|c|c|c|c|c|c|c|}
\hline & \multicolumn{6}{|c|}{ Panel I: Students under age 18 by marijuana use status } \\
\hline & $\begin{array}{l}\text { Marijuana use } \\
\text { in past } 30 \text { days }\end{array}$ & $\begin{array}{l}\text { No marijuana use } \\
\text { in past } 30 \text { days }\end{array}$ & $\begin{array}{l}\text { Marijuana use } \\
\text { in past } 30 \text { days }\end{array}$ & $\begin{array}{l}\text { No marijuana use } \\
\text { in past } 30 \text { days }\end{array}$ & $\begin{array}{c}\text { Marijuana use in } \\
\text { past } 30 \text { days }\end{array}$ & $\begin{array}{c}\text { No marijuana use } \\
\text { in past } 30 \text { days }\end{array}$ \\
\hline CAP Law & $\begin{array}{c}-.024 * * \\
(.011)\end{array}$ & $\begin{array}{l}-.005 \\
(.003)\end{array}$ & $\begin{array}{c}-.049 * * * \\
(.017)\end{array}$ & $\begin{array}{c}-.019 * * \\
(.008)\end{array}$ & $\begin{array}{l}-.016 \\
(.010)\end{array}$ & $\begin{array}{l}-.005 \\
(.004)\end{array}$ \\
\hline \multirow[t]{3}{*}{$\mathrm{N}$} & 132,292 & 526,449 & 154,338 & 628,640 & 173,283 & 695,849 \\
\hline & \multicolumn{6}{|c|}{ Panel II: Students under age 18 by binge drinking status } \\
\hline & $\begin{array}{l}\text { Binge drinking } \\
\text { in past } 30 \text { days }\end{array}$ & $\begin{array}{c}\text { No binge drinking } \\
\text { in past } 30 \text { days }\end{array}$ & $\begin{array}{l}\text { Binge drinking } \\
\text { in past } 30 \text { days }\end{array}$ & $\begin{array}{l}\text { No binge drinking } \\
\text { in past } 30 \text { days }\end{array}$ & $\begin{array}{l}\text { Binge drinking } \\
\text { in past } 30 \text { days }\end{array}$ & $\begin{array}{c}\text { No binge drinking } \\
\text { in past } 30 \text { days }\end{array}$ \\
\hline CAP Law & $\begin{array}{c}-.025 * * \\
(.011)\end{array}$ & $\begin{array}{l}-.003 \\
(.003)\end{array}$ & $\begin{array}{c}-.053 * * * \\
(.015)\end{array}$ & $\begin{array}{l}-.010 \\
(.007)\end{array}$ & $\begin{array}{c}-.022^{* *} \\
(.010)\end{array}$ & $\begin{array}{l}-.000 \\
(.004)\end{array}$ \\
\hline \multirow[t]{2}{*}{$\mathrm{N}$} & 157,807 & 498,489 & 179,920 & 600,106 & 200,195 & 666,199 \\
\hline & \multicolumn{6}{|c|}{ Panel III: Students under age 18 by drinking and driving status } \\
\hline CAP Law & $\begin{array}{l}-.040^{*} \\
(.022)\end{array}$ & $\begin{array}{l}-.006 \\
(.004)\end{array}$ & $\begin{array}{l}-.019 \\
(.031)\end{array}$ & $\begin{array}{c}-.022 * * \\
(.009)\end{array}$ & $\begin{array}{l}-.025^{*} \\
(.014)\end{array}$ & $\begin{array}{l}-.004 \\
(.005)\end{array}$ \\
\hline $\mathrm{N}$ & 63,663 & 592,444 & 69,645 & 703,196 & 77,314 & 769,129 \\
\hline
\end{tabular}

* Statistically significant at $10 \%$ level; ** at $5 \%$ level; *** at $1 \%$ level.

Notes: Each cell represents marginal effects from a Probit regression based on data from the YRBS for the period 1993-2013. All models control for the covariates listed in Table 2, state fixed effects, year fixed effects, and state-specific linear time trends. Regressions are weighted using population estimates from the National Cancer Institute's Surveillance Epidemiology and End Results Program. Standard errors, corrected for clustering at the state level, are in parentheses. 
Table 10. CAP Laws and the Probability of a School Shooting

\begin{tabular}{lccc} 
Panel I & $\begin{array}{c}\text { Shooting } \\
\text { Involving Any Death }\end{array}$ & $\begin{array}{c}\text { Shooting } \\
\text { Involving Suicide }\end{array}$ & $\begin{array}{c}\text { Shooting } \\
\text { Involving Homicide }\end{array}$ \\
\hline CAP Law & .073 & .112 & -.041 \\
& $(.010)$ & $(.069)$ & $(.081)$ \\
Panel II & $\begin{array}{c}\text { Shooting } \\
\text { Involving Any Death } \\
\text { (Shooters under } \\
\text { age 18) }\end{array}$ & $\begin{array}{c}\text { Shooting } \\
\text { (Shooters under } \\
\text { age 18) }\end{array}$ & $\begin{array}{c}\text { Shooting } \\
\text { Involving Homicide } \\
\text { (Shooters under } \\
\text { age 18) }\end{array}$ \\
\hline CAP Law & .014 & .038 & -.019 \\
& $(.152)$ & $(.087)$ & $(.106)$ \\
Panel III & $\begin{array}{c}\text { Shooting } \\
\text { Involving Any Death }\end{array}$ & $\begin{array}{c}\text { Involving Suicide } \\
\text { (Shooters ages 18+) }\end{array}$ & $\begin{array}{c}\text { Involving Homicide } \\
\text { (Shooters ages 18+) } \\
\text { (Shooters ages 18+) }\end{array}$ \\
\hline CAP Law & .058 & .094 & -.028 \\
& $(.136)$ & $(.077)$ & $(.081)$ \\
$\mathrm{N}$ & 1,173 & 1,173 & 1,173
\end{tabular}

* Statistically significant at $10 \%$ level; ** at $5 \%$ level; *** at $1 \%$ level.

Notes: Each cell represents a separate OLS estimate based on data on school-associated shooting deaths for the period 1991-2013. All models control for the covariates listed in Appendix Table 5, state fixed effects, year fixed effects, and state-specific linear time trends. Regressions are weighted using state populations. Standard errors, corrected for clustering at the state level, are in parentheses. 


\section{Appendix Table 1. Descriptive Statistics for Dependent Variables by Age}

\section{Students under age 18}

CAP Law $=1 \quad$ CAP Law $=0$

Full Sample

Carry Gun

Carry Any Weapon

$(.229)$

.180

(.384)

Carry Any Weapon at School

.057

(.233)

Weapon Threat at School

.072

(.259)

Missed School Due to Safety

.054

(.226)

.051

(.221)

.167

(.373)

.060

(.238)

.072

(.259)

.050

(.219)

Students ages 18+

Carry Gun

Carry Any Weapon

Carry Any Weapon at School

Weapon Threat at School

Missed School Due to Safety

$\begin{array}{ccc}.061 & .068 & .064 \\ (.240) & (.252) & (.245) \\ .188 & .185 & .187 \\ (.391) & (.389) & (.390) \\ .069 & .076 & .072 \\ (.253) & (.265) & (.258) \\ .064 & .066 & .065 \\ (.245) & (.248) & (.246) \\ .055 & .052 & .054 \\ (.227) & (.223) & (.226)\end{array}$

.054

(.225)

.175

(.380)

.059

(.235)

.072

(.259)

.053

(.223)

.064

(.245)

187

(.390)

.065

(.246)

.054

Notes: Weighted means with standard deviations in parentheses. 
Appendix Table 2. Descriptive Statistics for Dependent Variables by Race

White students under age 18

Carry Gun

CAP Law $=1 \quad$ CAP Law $=0$

Full Sample

Carry Any Weapon

$(.229)$

.186

(.389)

Carry Any Weapon at School

.058

$(.233)$

Weapon Threat at School

.069

(.254)

Missed School Due to Safety

.048

(.214)

.051

(.220)

.169

(.375)

.060

(.237)

.069

(.254)

.043

(.203)

.053

(.225)

.179

(.384)

.059

$(.235)$

.069

$(.254)$

.046

(.209)

Black students under age 18

Carry Gun

.059

(.236)

.059

.059

Carry Any Weapon

.141

(.235)

(.348)

.162

(.235)

.052

(.222)

Carry Any Weapon at School

(.369)

.151

(.358)

.087

Weapon Threat at School

(.282)

Missed School Due to Safety

.080

(.246)

.058

(.234)

.088

(.283)

(.271)

.083

.087

(.283)

.081

(.276)

(.273)

Notes: Weighted means with standard deviations in parentheses. 
Appendix Table 3. Descriptive Statistics for Falsification Outcomes Used in Table 8

\begin{tabular}{|c|c|c|c|c|}
\hline & $C A P$ Law $=1$ & $C A P L a w=0$ & Full Sample & Description \\
\hline Cigarette Use & $\begin{array}{l}.205 \\
(.404)\end{array}$ & $\begin{array}{l}.221 \\
(.415)\end{array}$ & $\begin{array}{l}.212 \\
(.408)\end{array}$ & $\begin{array}{l}=1 \text { if respondent smoked cigarettes in the past } 30 \\
\text { days, }=0 \text { otherwise }\end{array}$ \\
\hline Marijuana Use & $\begin{array}{l}.201 \\
(.401)\end{array}$ & $\begin{array}{l}.199 \\
(.399)\end{array}$ & $\begin{array}{l}.200 \\
(.400)\end{array}$ & $\begin{array}{l}=1 \text { if respondent used marijuana in the past } 30 \\
\text { days, = } 0 \text { otherwise }\end{array}$ \\
\hline Cocaine Use & $\begin{array}{l}.032 \\
(.177)\end{array}$ & $\begin{array}{l}.027 \\
(.162)\end{array}$ & $\begin{array}{l}.030 \\
(.171)\end{array}$ & $\begin{array}{l}=1 \text { if respondent used cocaine in the past } 30 \text { days. }= \\
0 \text { otherwise }\end{array}$ \\
\hline Binge Drinking & $\begin{array}{l}.247 \\
(.431)\end{array}$ & $\begin{array}{l}.251 \\
(.434)\end{array}$ & $\begin{array}{l}.249 \\
(.432)\end{array}$ & $\begin{array}{l}=1 \text { if respondent had } 5 \text { or more alcoholic drinks in } \\
\text { one sitting in the past } 30 \text { days, }=0 \text { otherwise }\end{array}$ \\
\hline Drunk Driving & $\begin{array}{l}.093 \\
(.291)\end{array}$ & $\begin{array}{l}.087 \\
(.281)\end{array}$ & $\begin{array}{l}.091 \\
(.287)\end{array}$ & $\begin{array}{l}=1 \text { if respondent drove after drinking in the } \\
\text { past } 30 \text { days, }=0 \text { otherwise }\end{array}$ \\
\hline Seatbelt Use & $\begin{array}{c}.094 \\
(.292)\end{array}$ & $\begin{array}{l}.140 \\
(.347)\end{array}$ & $\begin{array}{l}.112 \\
(.315)\end{array}$ & $\begin{array}{l}=1 \text { if respondent "never" or "rarely" wears a seat } \\
\text { belt, = } 0 \text { otherwise. }\end{array}$ \\
\hline Helmet Use & $\begin{array}{l}.783 \\
(.412)\end{array}$ & $\begin{array}{l}.782 \\
(.413)\end{array}$ & $\begin{array}{l}.782 \\
(.413)\end{array}$ & $\begin{array}{l}=1 \text { if respondent did not wear helmet while riding a } \\
\text { bicycle in the past } 12 \text { months, }=0 \text { if otherwise. }\end{array}$ \\
\hline Sex Partners & $\begin{array}{l}.252 \\
(.434)\end{array}$ & $\begin{array}{l}.240 \\
(.427)\end{array}$ & $\begin{array}{l}.247 \\
(.431)\end{array}$ & $\begin{array}{l}=1 \text { if respondent had more than one sex partner in } \\
\text { the past } 3 \text { months, = } 0 \text { if otherwise. }\end{array}$ \\
\hline Exercise & $\begin{array}{l}.232 \\
(.422)\end{array}$ & $\begin{array}{l}.239 \\
(.426)\end{array}$ & $\begin{array}{l}.235 \\
(.424)\end{array}$ & $\begin{array}{l}=1 \text { if respondent exercised one or fewer times in the } \\
\text { past week, }=0 \text { otherwise. }\end{array}$ \\
\hline Diet Pills & $\begin{array}{l}.062 \\
(.241)\end{array}$ & $\begin{array}{c}.063 \\
(.242)\end{array}$ & $\begin{array}{c}.062 \\
(.242)\end{array}$ & $\begin{array}{l}=1 \text { if respondent took a diet supplement in the past } \\
30 \text { days without a doctor's advice, }=0 \text { otherwise. }\end{array}$ \\
\hline Fruit & $\begin{array}{l}.136 \\
(.342)\end{array}$ & $\begin{array}{l}.138 \\
(.345)\end{array}$ & $\begin{array}{l}.136 \\
(.343)\end{array}$ & $\begin{array}{l}=1 \text { if respondent ate no fruits in the past week, = } 0 \\
\text { otherwise. }\end{array}$ \\
\hline
\end{tabular}

Notes: Weighted means with standard deviations in parentheses. 
Appendix Table 4. Descriptive Statistics for Dependent Variables by Various Risky Behaviors

Students under age 18 by marijuana use status

Students who report Students who do not marijuana use in past report marijuana use

\begin{tabular}{lcc} 
& 30 days & in past 30 days \\
\hline Carry Gun & .104 & .038 \\
& $(.305)$ & $(.192)$ \\
Carry Any Weapon & .299 & .140 \\
& $(.458)$ & $(.347)$ \\
Carry Any Weapon at School & .126 & .039 \\
& $(.332)$ & $(.195)$
\end{tabular}

Students under age 18 by binge drinking status

\begin{tabular}{lcc} 
& $\begin{array}{c}\text { Students who report } \\
\text { binge drinking in past } \\
\text { 30 days }\end{array}$ & $\begin{array}{c}\text { Students who do not } \\
\text { report binge drinking } \\
\text { in past 30 days }\end{array}$ \\
\hline Carry Gun & .104 & .033 \\
Carry Any Weapon & $(.305)$ & $(.180)$ \\
Carry Any Weapon at School & .290 & .133 \\
& $(.454)$ & $(.339)$ \\
& .120 & .036 \\
& $(.325)$ & $(.186)$
\end{tabular}

Students under age 18 by drinking and driving status

Students who report Students who do not

drinking and driving report drinking and

\begin{tabular}{lcc} 
& in past 30 days & driving in past 30 days \\
\hline Carry Gun & .182 & .038 \\
& $(.386)$ & $(.192)$ \\
Carry Any Weapon & .389 & .151 \\
& $(.487)$ & $(.358)$ \\
Carry Any Weapon at School & .194 & .044 \\
& $(.395)$ & $(.205)$ \\
\hline
\end{tabular}

Notes: Weighted means with standard deviations in parentheses. 
Appendix Table 5. Descriptive Statistics for State-Level School Shooting Analysis, 1991-2013

\begin{tabular}{|c|c|c|c|c|}
\hline & CAP Law $=1$ & CAP Law $=0$ & Full Sample & Description \\
\hline \multicolumn{5}{|l|}{ Dependent Variables } \\
\hline Shooting Involving Any Death & $\begin{array}{l}.512 \\
(.500)\end{array}$ & $\begin{array}{l}.340 \\
(.474)\end{array}$ & $\begin{array}{l}.441 \\
(.497)\end{array}$ & $\begin{array}{l}=1 \text { if there was a school shooting involving a death in state } s \text { during year } t \text {, }=0 \\
\text { otherwise }\end{array}$ \\
\hline Shooting Involving Suicide & .265 & .129 & $\begin{array}{l}.209 \\
(.407)\end{array}$ & $\begin{array}{l}=1 \text { if there was a school shooting involving a suicide in state } s \text { during year } t \text {, = } \\
0 \text { otherwise }\end{array}$ \\
\hline Shooting Involving Homicide & .425 & $\begin{array}{l}.277 \\
(.448)\end{array}$ & $\begin{array}{l}.364 \\
(.481)\end{array}$ & $\begin{array}{l}=1 \text { if there was a school shooting involving a homicide in state } s \text { during year } t \\
=0 \text { otherwise }\end{array}$ \\
\hline $\begin{array}{l}\text { Shooting Involving Any Death } \\
\text { (Shooters under age 18) }\end{array}$ & .225 & $\begin{array}{l}.183 \\
(.387)\end{array}$ & $\begin{array}{l}.207 \\
(.406)\end{array}$ & $\begin{array}{l}=1 \text { if there was a school shooting involving a death in state } s \text { during year } t \text { that } \\
\text { was committed by someone under the age of } 18,=0 \text { otherwise }\end{array}$ \\
\hline $\begin{array}{l}\text { Shooting Involving Suicide } \\
\text { (Shooters under age 18) }\end{array}$ & $\begin{array}{l}.140 \\
(.348)\end{array}$ & $\begin{array}{l}.072 \\
(.258)\end{array}$ & .112 & $\begin{array}{l}=1 \text { if there was a school shooting involving a suicide in state } s \text { during year } t \\
\text { that was committed by someone under the age of } 18,=0 \text { otherwise }\end{array}$ \\
\hline Shooting Involving Homicide & .136 & .126 & .132 & $=1$ if there was a school shooting involving a homicide in state $s$ during year $t$ \\
\hline $\begin{array}{l}\text { (Shooters under age 18) } \\
\text { Shooting Involving Any Death }\end{array}$ & $\begin{array}{c}(.343) \\
313\end{array}$ & $\begin{array}{c}(.332) \\
181\end{array}$ & $\begin{array}{c}(.339) \\
258\end{array}$ & that was committed by someone under the age of $18,=0$ otherwise \\
\hline$($ Shooters ages $18+)$ & $(.464)$ & $(.385)$ & $(.438)$ & someone $18+$ years of age, $=0$ otherwise \\
\hline $\begin{array}{l}\text { Shooting Involving Suicide } \\
\text { (Shooters ages } 18+\text { ) }\end{array}$ & $\begin{array}{l}.133 \\
(.340)\end{array}$ & $\begin{array}{l}.068 \\
(.251)\end{array}$ & $\begin{array}{l}.106 \\
(.308)\end{array}$ & $\begin{array}{l}=1 \text { if there was a school shooting involving a suicide in state } s \text { during year } t \\
\text { that was committed by someone } 18+\text { years of age, }=0 \text { otherwise }\end{array}$ \\
\hline $\begin{array}{l}\text { Shooting Involving Homicide } \\
\text { (Shooters ages } 18+\text { ) }\end{array}$ & .266 & $\begin{array}{l}.156 \\
(.363)\end{array}$ & $\begin{array}{l}.221 \\
(.415)\end{array}$ & $\begin{array}{l}=1 \text { if there was a school shooting involving a homicide in state } s \text { during year } t \\
\text { that was committed by someone } 18+\text { years of age, }=0 \text { otherwise }\end{array}$ \\
\hline \multicolumn{5}{|l|}{ Independent Variables } \\
\hline$\%$ Black & $\begin{array}{l}.309 \\
(.053)\end{array}$ & $\begin{array}{l}.290 \\
(.070)\end{array}$ & $\begin{array}{l}.301 \\
(.062)\end{array}$ & Percent of the state population that is black \\
\hline Mean Age & $\begin{array}{c}40.9 \\
(1.08)\end{array}$ & $\begin{array}{c}40.4 \\
(.841)\end{array}$ & $\begin{array}{c}40.7 \\
(1.02)\end{array}$ & State mean age \\
\hline$\%$ Male & $\begin{array}{l}.501 \\
(.003)\end{array}$ & $\begin{array}{l}.501 \\
(.003)\end{array}$ & $\begin{array}{l}.501 \\
(.003)\end{array}$ & Percent of the state population this is male \\
\hline Unemployment Rate & $(.062$ & $\begin{array}{l}.062 \\
(.017)\end{array}$ & $\begin{array}{c}.062 \\
(.020)\end{array}$ & State unemployment rate \\
\hline Per Capita Income & $\begin{array}{l}42,100 \\
(6,170)\end{array}$ & $\begin{array}{l}39,097 \\
(6,349)\end{array}$ & $\begin{array}{l}40,865 \\
(6,414)\end{array}$ & State income per capita (2013 dollars) \\
\hline \% Bachelor's Degree & $\begin{array}{l}.280 \\
(.053)\end{array}$ & $\begin{array}{l}.251 \\
(.048)\end{array}$ & $\begin{array}{l}.268 \\
(.053)\end{array}$ & Percent of the state population with a bachelor's degree \\
\hline
\end{tabular}




\begin{tabular}{|c|c|c|c|c|}
\hline Student-Teacher Ratio & $\begin{array}{c}16.2 \\
(3.50)\end{array}$ & $\begin{array}{c}15.5 \\
(3.14)\end{array}$ & $\begin{array}{c}15.9 \\
(3.37)\end{array}$ & Average student to teacher ratio \\
\hline School Lunch Program & $\begin{array}{c}.097 \\
(.021)\end{array}$ & $\begin{array}{c}.097 \\
(.019)\end{array}$ & $\begin{array}{c}.097 \\
(.020)\end{array}$ & State school lunch participation rate \\
\hline Teacher Salary & $\begin{array}{l}58,893 \\
(9,259)\end{array}$ & $\begin{array}{l}59,857 \\
(9,438)\end{array}$ & $\begin{array}{l}59,290 \\
(9,341)\end{array}$ & Average teacher salary (2013 dollars) \\
\hline Stand Your Ground Law & $\begin{array}{l}.199 \\
(.393)\end{array}$ & $\begin{array}{c}.145 \\
(.345)\end{array}$ & $\begin{array}{c}.177 \\
(.375)\end{array}$ & $=1$ if state has a stand your ground gun law, $=0$ otherwise \\
\hline Zero Tolerance Law & $\begin{array}{c}.900 \\
(.291)\end{array}$ & $\begin{array}{c}.736 \\
(.434)\end{array}$ & $\begin{array}{c}.833 \\
(.366)\end{array}$ & $=1$ if state has a zero tolerance school violence law, $=0$ otherwise \\
\hline Police Expenditures & $\begin{array}{c}246 \\
(86.6)\end{array}$ & $\begin{array}{c}210 \\
(92.2)\end{array}$ & $\begin{array}{c}231 \\
(90.6)\end{array}$ & State police expenditures per capita (2013 dollars) \\
\hline Police Employment & $\begin{array}{c}2.22 \\
(.380)\end{array}$ & $\begin{array}{c}2.44 \\
(.800)\end{array}$ & $\begin{array}{c}2.31 \\
(.600)\end{array}$ & State police employees per 1,000 population \\
\hline Property Crime & $\begin{array}{c}888 \\
(437)\end{array}$ & $\begin{array}{c}917 \\
(385)\end{array}$ & $\begin{array}{c}900 \\
(416)\end{array}$ & State adult property crime arrests per 100,000 population \\
\hline Violent Crime & $\begin{array}{c}439 \\
(279)\end{array}$ & $\begin{array}{c}384 \\
(204)\end{array}$ & $\begin{array}{c}416 \\
(252)\end{array}$ & State adult violent crime arrests per 100,000 population \\
\hline Democrat & $\begin{array}{c}.414 \\
(.493)\end{array}$ & $\begin{array}{c}.451 \\
(.498)\end{array}$ & $\begin{array}{c}.429 \\
(.495)\end{array}$ & $=1$ if state has a democratic governor, $=0$ otherwise \\
\hline Shall Issue Law & $\begin{array}{l}.545 \\
(.498)\end{array}$ & $\begin{array}{c}.506 \\
(.500)\end{array}$ & $\begin{array}{c}.529 \\
(.499)\end{array}$ & $=1$ if state has a shall issue gun law, $=0$ otherwise \\
\hline Anti-Bullying Law & $\begin{array}{l}.308 \\
(.454)\end{array}$ & $\begin{array}{c}.172 \\
(.368)\end{array}$ & $\begin{array}{c}.252 \\
(.426)\end{array}$ & $=1$ if state has an anti-bullying law, $=0$ otherwise \\
\hline Mental Health Parity & $\begin{array}{l}.505 \\
(.497)\end{array}$ & $\begin{array}{c}.291 \\
(.453)\end{array}$ & $\begin{array}{c}.417 \\
(.490)\end{array}$ & $=1$ if state has a mental health parity law, $=0$ otherwise \\
\hline Beer Tax & $\begin{array}{c}.304 \\
(.204)\end{array}$ & $\begin{array}{c}.293 \\
(.221)\end{array}$ & $\begin{array}{c}.299 \\
(.212)\end{array}$ & State beer tax (2013 dollars) \\
\hline $\mathrm{N}$ & 543 & 630 & 1,173 & \\
\hline
\end{tabular}

Notes: Weighted means with standard deviations in parentheses. 
Appendix Table 6. Leads and Lags of CAP Laws and the Probability of a School Shooting

\begin{tabular}{|c|c|c|c|}
\hline & $\begin{array}{c}\text { Shooting } \\
\text { Involving Any Death } \\
\text { (Shooters under } \\
\text { age 18) }\end{array}$ & $\begin{array}{c}\text { Shooting } \\
\text { Involving Suicide } \\
\text { (Shooters under } \\
\text { age 18) }\end{array}$ & $\begin{array}{c}\text { Shooting } \\
\text { Involving Homicide } \\
\text { (Shooters under } \\
\text { age 18) }\end{array}$ \\
\hline 2 Years before CAP Law & $\begin{array}{l}-.121 \\
(.082)\end{array}$ & $\begin{array}{c}-.135 \\
(.121)\end{array}$ & $\begin{array}{l}-.080 \\
(.081)\end{array}$ \\
\hline 1 Year before CAP Law & $\begin{array}{c}.016 \\
(.175)\end{array}$ & $\begin{array}{c}-.036 \\
(.083)\end{array}$ & $\begin{array}{c}-.092 \\
(.257)\end{array}$ \\
\hline Year of Law Change & $\begin{array}{c}-.056 \\
(.164)\end{array}$ & $\begin{array}{c}-.098 \\
(.115)\end{array}$ & $\begin{array}{l}-.109 \\
(.153)\end{array}$ \\
\hline 1 Year after CAP Law & $\begin{array}{c}-.072 \\
(.239)\end{array}$ & $\begin{array}{c}-.162 \\
(.137)\end{array}$ & $\begin{array}{c}-.088 \\
(.221)\end{array}$ \\
\hline $2+$ Years after CAP Law & $\begin{array}{c}.142 \\
(.225)\end{array}$ & $\begin{array}{c}.083 \\
(.151)\end{array}$ & $\begin{array}{c}.036 \\
(.238)\end{array}$ \\
\hline $\mathrm{N}$ & 1,173 & 1,173 & 1,173 \\
\hline
\end{tabular}

* Statistically significant at $10 \%$ level; $* *$ at $5 \%$ level; $* * *$ at $1 \%$ level.

Notes: Each column represents a separate OLS estimate based on data on school-associated shooting deaths for the period 1991-2013. All models control for the covariates listed in Appendix Table 5, state fixed effects, year fixed effects, and state-specific linear time trends. Regressions are weighted using state populations. Standard errors, corrected for clustering at the state level, are in parentheses. 